\title{
Serial persistence in individual real estate returns in the UK
}

Article

Accepted Version

Devaney, S., Lee, S. and Young, M. S. (2007) Serial persistence in individual real estate returns in the UK. Journal of Property Investment \& Finance, 25. pp. 241-273. ISSN 1463-578X doi: https://doi.org/10.1108/14635780710746911 Available at https://centaur.reading.ac.uk/29414/

It is advisable to refer to the publisher's version if you intend to cite from the work. See Guidance on citing.

To link to this article DOI: http://dx.doi.org/10.1108/14635780710746911

Publisher: Emerald Group Publishing Limited

All outputs in CentAUR are protected by Intellectual Property Rights law, including copyright law. Copyright and IPR is retained by the creators or other copyright holders. Terms and conditions for use of this material are defined in the End User Agreement.

\section{www.reading.ac.uk/centaur}

\section{CentAUR}

Central Archive at the University of Reading

Reading's research outputs online 


\title{
Serial Persistence in Individual Real Estate Returns in the UK
}

\author{
by \\ Steven P. Devaney ${ }^{\#}$ \\ Department of Real Estate \& Planning \\ University of Reading Business School \\ Reading, UK \\ e-mail: s.devaney@reading.ac.uk \\ and \\ Stephen L. Lee \\ Real Estate Finance and Investment Group \\ Faculty of Finance \\ Cass Business School \\ City University, London, UK \\ and \\ Michael S. Young \\ San Rafael, California, USA \\ \# Author for correspondence
}

Published in 2007 in the Journal of Property Investment \& Finance, Vol. 25, Issue 3, Pages 241-273

DOI: http://dx.doi.org/10.1108/14635780710746911

Acknowledgements: The authors would like to thank the anonymous referees for their comments. The analysis was undertaken whilst one of the authors was employed at IPD, and within its confidentiality restrictions. 


\title{
Serial Persistence in Individual Real Estate Returns in the UK
}

\begin{abstract}
Purpose - The paper examines individual level property returns to see whether there is evidence of persistence in performance, i.e. a greater than expected probability of well (badly) performing properties continuing to perform well (badly) in subsequent periods.
\end{abstract}

Methodology / Approach - The same methodology originally used in Young and Graff (1996) is applied, making the results directly comparable with those for the US and Australian markets. However, it uses a much larger database covering all UK commercial property data available in the Investment Property Databank (IPD) for the years 1981 to 2002 - as many as 216,758 individual property returns.

Findings - While the results of this study mimic the US and Australian results of greater persistence in the extreme first and fourth quartiles, they also evidence persistence in the moderate second and third quartiles, a notable departure from previous studies. Likewise patterns across property type, location, time, and holding period are remarkably similar.

Research implications - The findings suggest that performance persistence is not a feature unique to particular markets, but instead may characterize most advanced real estate investment markets.

Originality / value - As well as extending previous research geographically, the paper explores possible reasons for such persistence, consideration of which leads to the conjecture that behaviors in the practice of institutional-grade commercial real estate investment management may themselves be deeply rooted and persistent, and perhaps influenced for good or ill by agency effects.

Keywords - Property Returns, Performance Persistence, Valuation, Agency Effects

Paper type - Research paper

This article is (c) Emerald Group Publishing and permission has been granted for this version to appear here (http://centaur.reading.ac.uk/). Emerald does not grant permission for this article to be further copied / distributed or hosted elsewhere without the express permission from Emerald Group Publishing Limited. 


\section{Introduction}

The persistence of property returns is a topic of particular interest to real estate fund managers as it suggests that choosing those properties that will perform well in the future is as simple as looking at those that performed well in the past. Consequently, much effort has been expended to determine if such a rule exists in the real estate market. Serial persistence in real estate returns has been examined in the direct property markets in the US (Young and Graff, 1996, 1997), Australia (Graff, Harrington and Young, 1999) and the UK (Lee and Ward, 2001). Studies have also examined the serial persistence of publicly-traded (REIT) real estate (Graff and Young, 1997). The approach adopted for testing for persistence was much the same in each case. For each time period, the total returns of each property or REIT was calculated and the crosssectional returns ranked into quartiles. If the performance of real estate returns through time is independent, the use of quartile ranks implies that there is only a $25 \%$ probability of a property remaining in the same quartile return rank from one period to the next. A significant departure from the $25 \%$ theoretical probability can therefore be considered an indicator of serial dependence in performance.

This paper extends prior studies in three ways. First, it applies to the UK the same methodology as originally used in Young and Graff (1996), making the results directly comparable with those in the US and Australian property markets. Second, this study uses a much longer and larger database than in previous studies. The data cover commercial property returns for individual properties in the Investment Property Databank (IPD) for the years 1981 to 2002 - as many as 216,758 observations and 30,000 property time-series returns. This should, therefore, provide a strong statement on the issue of persistence in individual real estate returns.

Third, this study debates a number of possible reasons why properties might persist in their relative performance. This is an important issue, not only from the perspective of investment strategy, but also in terms of the operation of the market. If relative persistence is found to occur,

This article is (c) Emerald Group Publishing and permission has been granted for this version to appear here (http://centaur.reading.ac.uk/). Emerald does not grant permission for this article to be further copied / distributed or hosted elsewhere without the express permission from Emerald Group Publishing Limited. 
then it may indicate institutional factors that prevent the market from operating efficiently. Alternatively, it may demonstrate the impact of behavioral influences or reveal locational forces that reinforce the success of certain regions or urban areas. The paper also considers whether these reasons explain differences between UK, US and Australian findings.

\section{Previous Studies}

The analysis for the US direct institutional-grade real estate market (Young and Graff, 1996, 1997) used annual returns from the NCREIF database, over the period 1978 to 1994 . The study was based on the return performance of fifty Metropolitan Statistical Areas (MSA) that had at least one occurrence of two consecutive years of data, the total number of MSAs ranging from eight in 1978 to forty-four in 1991. The data was also decomposed into five property types; Office, Retail, Warehouse, $R \& D$ and Apartments. The results for the five property types indicated that for the two extreme quartiles, the highest and lowest ranks, serial persistence was demonstrated with almost complete certainty from one year to the next. However, the persistence tended to fade beyond this, except for Apartments where serial persistence was extended to runs of two and three years. For the combined data, serial persistence was exhibited for one, two, three, four and five years, indicating that real estate returns exhibit persistence for some considerable time. In contrast, little or no significant serial persistence was found for the second and third quartiles, except for Warehouses over one year and the combined data for one- and two- years runs. In other words, persistence is exhibited at the extremes of performance, the best and the worst properties, in any one year but not by properties around the median.

Graff et al (1999) applied the same approach to the Australian direct institutional-grade property market using annual data over the period from 1985 to 1997 from the Property Council of Australia database. The data decomposed into three property types: Office, Retail and Industrial. The results of the analysis showed that serial persistence was exhibited by Office and

This article is (c) Emerald Group Publishing and permission has been granted for this version to appear here (http://centaur.reading.ac.uk/). Emerald does not grant permission for this article to be further copied / distributed or hosted elsewhere without the express permission from Emerald Group Publishing Limited. 
Retail property at the extreme quartiles (the first and fourth) and for the median quartiles (second and third combined), but that Industrial properties exhibited serial independence in all categories. In addition, there was a qualitative difference in the Office data between CBD and non-CBD properties. In particular, the Office data in the CBD locations exhibited serial persistence in all quartiles, but no serial persistence was found for the non-CBD data, while the combined data exhibited statistical significance in all quartiles. In other words, superior performance is generally followed by continued superior performance and inferior performance by continued inferior performance.

Lee and Ward (2001) tested the persistence in performance of direct real estate returns in the UK between 1981 and 1996 applying the same quartile ranking method used in previous studies. However, the authors then used a Markov Chain approach that allowed the estimation of several parameters of interest not readily available from the binomial approach of Young and Graff (1996, 1997). The sample data consisted of the total returns on properties in three types, Retail, Office, and Industrial property, in various local authority districts (essentially towns) in the UK, to give a total of 392 asset possibilities. The authors found that the observed persistence in performance of real estate returns in other countries was confirmed and appeared to be fairly stable between 1981 and 1996. Second, the persistence did not appear to be driven by volatility, and was robust across sectors, regions, and unaffected by size variations.

The authors also tested a number of trading strategies and concluded that real estate investors would be better off, in terms of higher returns coupled with a lower turnover rate, by purchasing properties identified as the best in one period and only selling those that fall below the median in the next, rather than concentrating investment in properties from the first quartile. Such a strategy outperformed a random approach and one that assumed absolute persistence in returns, even after transaction costs. The evidence suggested two important rules-of-thumb for property fund managers who wish to maximize performance: (1) avoid properties with below average performance and (2) invest in properties in the upper quartile of performance in one year as they

This article is (c) Emerald Group Publishing and permission has been granted for this version to appear here (http://centaur.reading.ac.uk/). Emerald does not grant permission for this article to be further copied / distributed or hosted elsewhere without the express permission from Emerald Group Publishing Limited. 
have a higher-than-average chance of achieving above average returns next year. In other words, a fund manager would be advised to stay with the best and avoid the worst.

Another study of the UK market has more recently been conducted by Marcato and Key (2005). Using annual and monthly frequency data, this too examined persistence, but through the evaluation of trading strategies based on its existence rather than via a direct test. They found that a momentum strategy (investing in segments that had previously shown high returns) produced significantly higher returns than the IPD benchmark, which represented a buy-and-hold strategy, but some of the benefits were eroded once transaction costs were taken into account. The authors also found some evidence of mean-reversion after 36 months. Their analysis was based on returns of ten market segments, though, and so represents a further step - beyond the town/MSA level - from actual property returns.

Finally, using monthly, quarterly, and annual data over the ten-year period from January 1987 to December 1996, Graff and Young (1997) find that the results for publicly-traded REITs are somewhat different. In particular, the data showed a variety of conclusions depending on the sample frequency. For the annual data, like the results for the direct real estate market, persistence was observed at the two extremes (i.e., combined first and fourth quartiles) while the two moderate quartiles (i.e., combined second and third quartiles) were statistically insignificant from the theoretical $25 \%$ probability. In contrast, the quarterly data showed a lack of serial persistence in the extreme and the moderate quartiles. The monthly returns displayed yet different results, with the extreme quartiles showing negative persistence. That is, a REIT in the fourth and especially the first quartile have less than a $25 \%$ chance of being in that quartile in the subsequent period. The negative persistence was more pronounced for large-capitalization REITs than for small-capitalization REITs.

This article is (c) Emerald Group Publishing and permission has been granted for this version to appear here (http://centaur.reading.ac.uk/). Emerald does not grant permission for this article to be further copied / distributed or hosted elsewhere without the express permission from Emerald Group Publishing Limited. 


\section{Data}

Data on institutional-grade real estate assets in the UK are collected by Investment Property Databank (IPD), a commercial organisation that provides independent performance measurement and benchmarking services to property investors. Their databases are comprised of individual property data provided by contributing investors that include insurance companies, pension funds, and publicly-listed property companies. There were 232 funds contributing to the UK database at the end of 2002, giving information on over 11,400 properties with an aggregate value of $£ 102$ billion. It is estimated that this was equivalent to $75 \%$ of the total property investments held by UK institutions and listed property companies (IPD, 2003) [1].

The data used in this study are annual total returns for individual properties over the period 1981 to 2002. All of the properties in the dataset are reappraised each December, so the annual returns reflect that calendar year. Data on both historic and currently held properties were used, so as many as 30,000 property records were utilised in the analysis. Returns for a property were only used for those years where it was a standing investment, i.e., held in an investor portfolio and not traded or subject to development or significant improvement expenditure. Furthermore, a property needed at least two consecutive periods as a standing investment for the persistence test to be performed.

Returns for transaction periods are therefore not included and, where a transaction is made between two funds in the database, the returns under the new fund's ownership are recorded as a separate observation. The exclusion of returns in a trading period may seem odd, given that movement from these periods to the next (or from the previous, in the case of a sale) could be of some interest, but as transactions happen at different points over the year, a full annual return can rarely be computed for them. In addition, this factor, together with the typically long holding periods for commercial real estate assets, makes the use of solely price-based returns impossible,

This article is (c) Emerald Group Publishing and permission has been granted for this version to appear here (http://centaur.reading.ac.uk/). Emerald does not grant permission for this article to be further copied / distributed or hosted elsewhere without the express permission from Emerald Group Publishing Limited. 
since regular observations are required. This situation is common to most empirical real estate analysis.

As in previous studies, disaggregation into property types was performed. Properties not classified by IPD into one of the three main property investment sectors (Office, Retail or Industrial) were excluded from the analysis [2]. It is worth noting that, unlike in the US, Residential / Apartment properties do not form a significant part of most institutional portfolios. The data were also disaggregated into three super-geographical regions (London, Rest of South East, and the Rest of the UK). The total number of return observations over the twenty-two-year period was 216,758. By quartile rank over the entire period, 54,206 sample returns fell into the first quartile, 54,188 into the second quartile, 54,188 into the third quartile, and 54,176 into the fourth quartile.

\section{Methodology and Confidence Interval Estimation}

The methodology in this study is as follows: for each annual sample period, individual property returns are grouped into quartiles and the quartile rank is recorded [3]. Successful persistence is then defined as a property staying in the same quartile rank in the subsequent annual period, and unsuccessful persistence as the property appearing in a different quartile rank in the subsequent annual period. Because the returns are grouped into quartiles, the theoretical probability of repetitive quartile rankings is $25 \%$, if consecutive quartile rankings for each property are serially independent, the typical assumption made by researchers. Accordingly, statistically significant departures from 25\% among sample persistence statistics are deemed evidence that asset returns are not serially independent.

Within each quartile group, the incidence of serial runs of uniform quartile rank were examined. The test statistic is the sample incidence of successful persistence (i.e., the observed rate at which a repetitive quartile rank occurs in the period immediately subsequent to a run of

This article is (c) Emerald Group Publishing and permission has been granted for this version to appear here (http://centaur.reading.ac.uk/). Emerald does not grant permission for this article to be further copied / distributed or hosted elsewhere without the express permission from Emerald Group Publishing Limited. 
identical quartile rankings over one, two, three, or four sample periods). The persistence counting procedure is identical to that used in previous studies in the US and Australia noted above and the actual counting technique is described more fully in the Appendix of Graff, Harrington, and Young (1999).

To determine whether quartile performance is serially dependent, confidence intervals for the binomial distribution were calculated under the assumption that the probability of repeating quartile performance is $25 \%$. As with the counting procedure, a complete explanation of confidence interval estimation is available in prior publications. See Young and Graff (1996), for example.

\section{Tests and Results}

Table 1 shows the number of samples arranged by year, by three property types, and by three distinct regions. The performance persistence results are shown in tabular and graphical form, described more fully as follows.

[Take in Table No. 1]

As shown in Table 2, Panel A, performance persistence is statistically significant in the cross-sectional distribution of the full set of IPD property returns for the years 1981 to 2002. Statistically significant performance persistence is found in each quartile following runs of 1 year, 2 years, 3 years, and 4 years. Combining the first and fourth quartiles into an extremequartile group and combining the second and third quartiles into a moderate-quartile group, we find that there is statistically significant persistence in the extreme-quartile group following runs of 1 through 4 years, and that there is somewhat lesser statistically significant persistence in the 
moderate-quartile group following runs of 4 years, while statistically significant persistence following runs of 1 through 3 years is the same as in the extreme-quartile group.

In this panel and in all subsequent panels, statistical significance is similar if not identical across all quartiles, across most runs of 1 through 4 years, and across extreme-quartile and moderate-quartile aggregations. What is particularly striking, however, is the quantitative differences between the extreme- and moderate quartiles in all cases without exception.

[Take in Table No. 2]

When we disaggregate properties by type, patterns of return persistence are nearly identical to the aggregate. Panels B, C, and D of Table 2 show persistence results of Office, Retail and Industrial property groupings respectively. Comparing these results to the aggregate results in Panel A, we find that the quartile serial persistence across runs of 1 to 4 years is statistically similar to that of Panel A. The relatively minor although notable difference is evident in the extreme- versus moderate-quartile groupings where strong serial persistence is evident across runs of 1 to 4 years for all three property types for the extreme-quartile groupings, but trails off for the moderate quartile grouping as runs increase in length.

Panels E, F, and G of Table 2 show persistence results for London, Rest of South East, and the Rest of the UK regional groupings. Once again, irrespective of region, the patterns mimic those observed in the all property aggregates and the property type groupings. The same quantitative and qualitative differences between the extreme-quartile and moderate-quartile groupings are virtually indistinguishable from the results shown in Panels A through D. Data were not available to determine whether the property type distributions across the regional groupings were identical, but we suspect that they are not, especially with regard to the Rest of the UK grouping. If this conjecture is correct, the similarities of patterns across property type and

This article is (c) Emerald Group Publishing and permission has been granted for this version to appear here (http://centaur.reading.ac.uk/). Emerald does not grant permission for this article to be further copied / distributed or hosted elsewhere without the express permission from Emerald Group Publishing Limited. 
region appears to be a fundamental or intrinsic characteristic of the commercial real estate market rather than a function of its property type or regional distinction.

Figure 1 depicts graphically the results of Table 2 for runs of 1 year. Horizontal bars on the graphs indicate the percent of successes and the vertical bars indicate the $95 \%$ confidence intervals. Additionally, the data for all properties and property type and regional groupings have been split into three time periods: the full 1981 to 2002 period, the more recent 1992 to 2002 period, and the earlier 1981 to 1991 period. The vertical axes of the graphs within a single type grouping are identical to facilitate comparisons over different time periods.

[Take in Figure No. 1]

Figure 1 shows quite clearly the degree to which persistence in the extreme quartiles differs from persistence in the moderate quartiles in nearly all groupings. Across quartiles, there is a tendency for somewhat greater persistence in the fourth quartile, the quartile with poorest relative performance, for all properties, Office, Retail (except in the 1981 to 1991 period), South East, and Rest of UK (except in the 1981 to 1991 period). Industrial properties across the entire 1981 to 2002 and especially across the 1992 to 2002 periods exhibit the greatest departure from the patterns observed for other groupings. Particularly notable is the 1992 to 2002 pattern for Industrial properties, where the performance persistence declines progressively from the first to the fourth quartile.

In the aggregate and in all groupings except Industrial, performance persistence in the moderate quartiles is less pronounced in the 1992 to 2002 period than in the earlier 1981 to 1991 period.

Table 3 shows results for four different groups of holding periods: 2 to 5 years, 6 to 10 years, 11 to 15 years, and 16 to 20 years. As in Table 2, these results are computed for persistence runs from 1 to 4 years duration. The results for all four holding period clusters are similar to those

This article is (c) Emerald Group Publishing and permission has been granted for this version to appear here (http://centaur.reading.ac.uk/). Emerald does not grant permission for this article to be further copied / distributed or hosted elsewhere without the express permission from Emerald Group Publishing Limited. 
reported in Table 2, namely more persistence in the extreme quartiles than in the moderate quartiles extending to runs of 1 to 4 years. While persistence does not appear to vary materially across holding period, the pronounced fourth quartile persistence across all four holding period groupings is a notable departure from performance persistence in the other three quartiles.

[Take in Table No. 3]

It seems odd that investors or their managers would hold on to properties that exhibited repeatedly poor relative performance for upwards of twenty years of ownership. Graphical depictions of Table 3 for runs of 1 year are shown in Figure 2, which makes the exceptional fourth quartile performance most evident.

[Take in Figure No. 2]

It could be argued that there should be a difference in persistence in "Up" and "Down" markets. Up markets are characterized by all sectors and regions showing good, but divergent performance. In other words, although all sectors are achieving good capital gains, some are showing dramatic performance while others are only doing reasonably well. In contrast, in a downturn, there tends to be a convergence in performance, all of it bad, so all sectors show equally poor returns. This suggests that in an Up market there is likely to be even stronger levels of persistence in the first and fourth quartiles than in the Down market. Therefore, the data was classified into Up and Down markets to test this proposition. An Up market is defined as those years showing a positive deviation from the long-term trend in the IPD Annual Index, while Down markets are those years with a negative deviation. Up markets include the calendar years 1986 to 1989 and 1996 to 2002, while Down markets include the 1981 to 1985 and 1990 to 1995 
periods. Given the relatively short periods for these cycles, the persistence data for runs of more than 1 or 2 years diminish in explanatory power and as such are not discussed.

Table 4 shows the serial persistence results for all properties (Panels A and B) and for Office properties (Panels C and D) in Up and Down markets. The patterns that by now are becoming familiar hold, namely that the extreme-quartiles are more persistent than the moderate quartiles in the aggregate and in the Office group during Up markets. Furthermore, there is little to distinguish Up and Down market persistence patterns for the aggregate of all properties and even the magnitudes of the quartile persistence figures are nearly identical in the first and fourth quartiles. The Up and Down market persistence pattern of Office properties differ a bit, most notably in the first quartile in Down markets that are quite low, relatively speaking, and in the fourth quartile in Down markets that are quite high. Figure 3, which shows graphically the 1-year persistence results from Table 4, makes these contrasting patterns most evident.

[Take in Table No. 4]

[Take in Figure No. 3]

Figure 4 combines persistence results from Young and Graff (1996) involving US NCREIF data, from Graff, Harrington, and Young (1999) involving Property Council of Australia (PCA) data, and the present study, all for runs of 1 year in the aggregate and by the three property types. Although time periods differ and the sample sizes produce substantially different confidence intervals, similarities among commercial property persistence results are evident from these graphs. In particular, the greater persistence in the first and fourth quartiles versus the second and third quartiles is similar across all three national data sets. Office properties have a similar crossnational pattern, although somewhat more muted in the first quartile persistence and generally more pronounced in the fourth quartile results.

This article is (c) Emerald Group Publishing and permission has been granted for this version to appear here (http://centaur.reading.ac.uk/). Emerald does not grant permission for this article to be further copied / distributed or hosted elsewhere without the express permission from Emerald Group Publishing Limited. 
US results for Retail properties and Australian results for Industrial properties are more dissimilar than for like-property results for the other countries. In particular, the US Retail property results have especially high first quartile persistence while especially low fourth quartile persistence. Australian Industrial property results are especially low for first quartile persistence and notably low for fourth quartile persistence as well. These exceptions are discussed in the prior research and need not be elaborated upon here except to say that there are or can be trends or circumstances of attention paid to particular property types, in particular, time periods that can lead to possibly atypical patterns or performance behavior. The "fads" discussed in the next section are likely contributors to these seemingly anomalous results.

[Take in Figure No. 4]

\section{Possible Sources of Persistence}

A number of reasons might be advanced to explain persistence in performance and the greater persistence in the UK compared with that in the US and Australia.

First, there may be differences in the provision of valuations that, in turn, have implications for their independence. Internally produced valuations, for instance, might attempt to portray the performance of properties in a good light and maintain this for as long as possible, leading to serial persistence in individual property returns. A second, but related, argument might be that even where valuations are conducted by an external valuer, undue pressure is brought to bear to produce figures that benefit the organisation, again leading to serial persistence.

Third, even if valuations are independent, the use of comparable evidence in arriving at a valuation itself may induce serial persistence in property returns. The argument is that the comparables used to arrive at a current estimate of price are themselves based on knowledge of previous valuations from similar properties and that this tendency to recycle valuations has the

This article is (c) Emerald Group Publishing and permission has been granted for this version to appear here (http://centaur.reading.ac.uk/). Emerald does not grant permission for this article to be further copied / distributed or hosted elsewhere without the express permission from Emerald Group Publishing Limited. 
effect of incorporating knowledge of previous prices in the current return, leading to serial persistence.

Grossman and Stiglitz (1976) assert that, due to the paucity of data from market prices, a thin market will display uniformity of investor beliefs about asset prices, which in the real estate context leads to fads for a particular property type or region. This uniformity of belief may itself lead to persistence in real estate returns, especially if the number of firms undertaking the external valuations is so few that the market evidence is averaged out and thereby constrains the variability in valuation (Graff and Webb, 1997).

Another possible factor is location. Properties in 'good' locations within an area may persistently perform well, particularly if there are constraints that restrain a supply side response to demand for space in that locality.

Finally, lease term variations across property types may also account for differences in persistence. As terms lengthen, for example, property economics may take on a more bond-like character where annual valuations and the returns derived from them become synchronized with interest rates or capitalization rates, in real estate parlance. Each of these arguments is examined in turn.

Agency Effects, Internal and External

The majority of valuations supplied to IPD and used in their UK annual index are valuations of individual properties in portfolios by external rather than internal valuers. An External Valuer is defined in UK valuation standards as “...a valuer who... has no significant financial linkages with the client either as a director or employee,” (Royal Institution of Chartered Surveyors, 2003: G1). External Valuers, therefore, should produce valuations that are more impartial and which do not put an organisation or a particular property in the most favourable light. This would imply that the first argument cannot account for the greater serial persistence observed in UK property returns.

This article is (c) Emerald Group Publishing and permission has been granted for this version to appear here (http://centaur.reading.ac.uk/). Emerald does not grant permission for this article to be further copied / distributed or hosted elsewhere without the express permission from Emerald Group Publishing Limited. 
The Carsberg Report (Royal Institution of Chartered Surveyors, 2002), though, notes that the fee-earning relationship that exists between the valuer and client may threaten an External Valuer's objectivity. It states that “close personal relationships...could lead to insufficient questioning of factors affecting the valuation” (p.21) and "in any relationship involving payment of a fee, particularly where repeat business is possible, the objectivity and independence of the service provider may be at risk.” (p.22).

In particular, a study by Baum et al (2000) on the valuation process in the UK raised concerns about what are known as 'draft valuation meetings' at which the valuer produces preliminary figures for discussion with the client prior to producing the final valuation. Such meetings could provide the client with an opportunity to influence the outcome of the valuations to the benefit of the organisation. Baum et al (2000: 40) reported that client influence “...does occur and valuations can be influenced by clients.” However, they noted that such influence is short-lived and could be counter productive. Indeed, they found that any short-term pressure to push valuations upward was not evident over the long term "as valuations would be forced to recover the position over future periods” Baum et al (2000: 6).

It would seem, therefore, that any influence on external valuers is unlikely to account for the greater persistence found in annual returns to real estate in the UK compared with the US and Australia, despite the issues noted above, especially for runs of greater than 1 year or perhaps 2 years.

\section{Anchoring}

The argument that the valuation procedures used to derive price can account for the large amount of persistence in real estate returns is often discussed. Valuers in the UK typically use comparable evidence to estimate price (Crosby, 1990). Quan and Quigley $(1989,1991)$ argue that if valuers use comparable evidence to derive price, the optimum strategy is to use a weighted average of the previous value and the most recent market evidence, although the authors supply 
no empirical evidence to support the conjecture. The smooth nature of real estate returns, therefore, arises from the relative uncertainly of the variability of movements in the market in general and that of the property being valued (Brown and Matysiak, 2000). In addition, since 1990, there has been a significant increase in the incidence of valuers being sued for negligence (Crosby et al, 1998), the only defence to which is that the valuer followed 'correct' procedures and hierarchies of evidence in arriving at their valuation. The greater the uncertainly in current market sentiment, the less likely it is to be used, all of which leads valuers to see the previous valuation as the only hard evidence. Consequently, it is rational for valuers to put more weight on knowledge of the previous valuation and less weight on more nebulous current market sentiment that cannot be proved, Quan and Quigley $(1989,1991)$.

Diaz (1990a, 1990b, and 1997) and Diaz and Wolverton (1998) have shown that valuers inadequately adjust from their previous appraisal in performing current valuations, a process known as 'anchoring.' Thus, the estimate of the current price of the property is biased towards the initial starting figure of the previous valuation and so will give rise to serial persistence in returns. However, there is no evidence to suggest that valuers in the UK anchor more to previous valuations than their counterparts in the US or Australia. In other words, anchoring alone is unlikely to account for the greater persistence in real estate returns in the UK relative to that in the US and Australia.

Even if anchoring is found to be an important source of persistence, there are relatively simple and inexpensive solutions that managers could take to alleviate the problem. In particular, Graff and Young (1999) recommend switching or rotating valuers on a more frequent basis.

\section{Number and Dispersion of Independent Valuers}

When using current market evidence within the valuation process, a noticeable difference can be seen between the US and UK. In the US market, Graff and Webb (1997) observe that knowledge is locally-based and under the control of a small handful of local firms. Thus, the market 
sentiment of one locality is likely to be ironed out among this small number of firms leading to a uniformity of belief as to the prospects for properties in that locality. This has the effect of clients with property in that area updating their portfolios based on the same market data that constrains variation in values, leading to persistence in returns. In particular, this may explain why the properties in the fourth quartile show greatest level of persistence, as it may be these properties that require the strongest amount of market evidence to shift the valuer away from the previous valuation.

Institutions may also develop fads for certain property types and locations, a process that will continue for a long time until the evidence is so overwhelming that the particular property type or location loses its charm. In other words, the persistence in real estate returns can be explained by the faddish behavior on the part of investors and the control of market data in the hands of only a few firms. However, these phenomena will be limited across the US and Australia because appraisal firms in these countries are more disperse than in the UK. Thus, although there may be a "house view" of certain property types and regions by firms, this is likely to be limited to that individual firm. Any uniformity of belief about a particular region is therefore unlikely to permeate across all investor portfolios with property in that region, thereby reducing the amount of cross serial correlation in returns and mitigating the level of serial persistence in real estate returns.

In contrast, in the UK, the number of firms undertaking the majority of external valuations is very small and they are national in size. For instance, the Carsberg Report (Royal Institution of Chartered Surveyors, 2002: 14) observed that, as of December 2000, 64.7\% by capital value of the properties in the IPD Annual Index were valued by five firms, and 37.7\% by three firms. For the smaller IPD Monthly Index, the corresponding figures (as of November 2001) were 79.6\% by the top five valuation firms and $62.4 \%$ by the top three firms. In addition, if firms were to 'pool' market knowledge, the 'house view' of one firm, which itself is a distillation of market sentiment

This article is (c) Emerald Group Publishing and permission has been granted for this version to appear here (http://centaur.reading.ac.uk/). Emerald does not grant permission for this article to be further copied / distributed or hosted elsewhere without the express permission from Emerald Group Publishing Limited. 
from its own valuers for each property type and region, could be further refined across all valuation firms, leading to a uniform market view displaying little variation.

Thus, when undertaking an external valuation for one client, the valuation firm not only incorporates knowledge of the previous valuation of the individual property, but it will also use the market view for all properties of a similar type from across the UK. Such a process is likely to lead to serial persistence in the returns of individual properties for one client and induce cross serial correlation in similar properties for all clients, inadvertently leading to even greater persistence across individual properties in the UK compared with the US and Australia. However, the extent to which this explains the greater serial persistence found in UK properties is not known and deserving of future research.

\section{Location}

Although there are similarities in persistence at a regional level, differences in location at a micro-level may account for persistence. This could particularly be the case if supply side responses to demand for space are constrained. A property in a good location within an area may not only benefit from an upturn in demand, but also see its advantage maintained over subsequent periods if new development cannot respond quickly owing to planning restrictions or land constraints.

This factor could also explain the greater persistence in UK returns relative to the US and Australia. However, it does not immediately explain the property type patterns, where Retail might be expected to be most influenced by these effects. Retail activity within UK towns and cities is usually concentrated around a tightly defined prime pitch and planning policies often seek to protect town centres and restrict 'out-of-town' development, which would help maintain the advantage of the prime pitch and any existing successful out-of-town sites. Yet Retail does not exhibit notably greater return persistence than the other property types.

This article is (c) Emerald Group Publishing and permission has been granted for this version to appear here (http://centaur.reading.ac.uk/). Emerald does not grant permission for this article to be further copied / distributed or hosted elsewhere without the express permission from Emerald Group Publishing Limited. 
While IPD is a rich source of return information, it does not contain detailed data on the quality or micro-locational aspects of properties, preventing further examination of this hypothesis at the present time.

\section{Lease Terms}

Lease term variations across property types may also account for differences in persistence. As terms lengthen, for example, property economics may take on a more bond-like character where annual valuations and the returns derived from them become synchronized with capitalization rates.

Although the data shown in Table 5 should be viewed as preliminary and perhaps incomplete, they are nonetheless indicative of the differences in lease terms by property type between the UK and the US. For example, taking the simple averages of the lease terms by property type in Panel A, the IPD data, and contrasting them with the 2000 to 2004 averages in Panel B, the RREEF data, it can be seen that the UK (IPD) average Office lease terms are about 7.7 years versus the US (RREEF) average Office lease terms of about 4.6 years. Similarly, UK average Retail lease terms are about 9.7 years versus a US average of about 5.7 years, and the UK average Industrial lease terms are about 7.3 years versus a US average of about 3.4 years.

\section{[Take in Table No. 5]}

These relative differences in average lease terms would indicate that considerably more of the total value estimate of UK properties is comprised of current rather than future leases compared to the composition of the total value estimate of US properties. Because there is less uniformity of opinion about future market rents, this difference may account for the greater observed persistence of UK properties relative to US properties across the board. The historic tendency for very long (25+ year) leases in UK institutional grade property means that this is also 
likely to hold for the early years of the data. Meanwhile, another feature of UK leases, upwardonly rent review clauses, which continue to be almost universal in leases with rent reviews (Crosby et al, 2005), further contribute to a more bond-like cash flow profile, particularly in periods where over-renting occurs. This may also explain why Down markets did not show less persistence than Up markets, despite the prior expectation that they should.

Though it would be helpful to expand this comparison to Australia, at present, no similar data has been published on the average lease terms granted within Australian real estate portfolios. While it is possible to obtain an indication of typical CBD (office) lease terms (CBRE, 2005), this is not sufficient for further comment here.

\section{Conclusions}

This study has examined persistence in relative investment return performance for UK institutional-grade commercial property during the twenty-two-year interval 1981 through 2002. Annual returns data was also divided into three property type subgroups: Office, Retail, and Industrial, and by three regions; London, the South East, and the Rest of the UK. Additional tests analyzed the data by holding period and market state.

The empirical results demonstrate that total returns from properties within the IPD UK database between 1981 and 2002 exhibit serial dependence across all four quartiles of relative returns for all properties aggregated, as well as across each of the three property types and regions. Therefore, the results suggest that investors could have bought and sold properties on the basis of performance in the previous period in order to improve their returns. However, if this were possible, then it may be asked why such strategies were not implemented, causing this dependence to disappear through the process of arbitrage.

To this, there may be a number of answers. The simplest is that, in the absence of a central and public marketplace, such rankings are unobservable. Hence, while investors can act upon

This article is (c) Emerald Group Publishing and permission has been granted for this version to appear here (http://centaur.reading.ac.uk/). Emerald does not grant permission for this article to be further copied / distributed or hosted elsewhere without the express permission from Emerald Group Publishing Limited. 
relative performance within their own portfolios, they will have limited information about other properties and, indeed, about whether such a trading rule exists. Second, whilst this study has debated explanations relating to appraisal process, the absence of transaction information in the dataset does prevent testing of an alternative price basis to returns. Future research could seek to construct a database across different ownerships to see whether or not persistence continues past a trading event.

Third, even if persistence were observable, barriers may exist to taking advantage of it. In particular, some of the benefits from pursuing a persistence trading/selection rule may be eliminated by transaction costs and delays, as suggested by Marcato and Key (2005) in their study of trading strategies. There could also be further restrictions in terms of asset availability. Finally, good relative performance is not a guarantee that a property will perform well in absolute terms and this would further count against such a strategy in certain market conditions [4].

The UK results contrast markedly from results of similar studies of institutional-grade commercial property returns in the US and Australia, where persistence tended to be statistically significant in the extreme first and fourth quartiles, but statistically independent in the moderate second and third quartiles. However, while the statistical differences among UK, US, and Australian property return quartiles exist, the UK pattern of generally more persistence in the extreme quartiles than in the middle quartiles is qualitatively similar to both the US and Australia. This leads to suspicion that the general commercial real estate risk profile among the three countries is of the same general character and that the differences, notably evident in the middle quartiles, result from agency or behavioral aspects of the management of the real estate investment management business [5].

Such conclusions are at odds with the prevailing finance theory-based assumption about real estate risk, and once again call into question current beliefs about statistically-derived risk proxies and Modern Portfolio Theory-based portfolio construction applications for real estate. In 
particular, if MPT or the Efficient Markets Hypothesis are appropriate models for equity real estate, these findings of performance persistence should not be observed. Moreover, that persistence in extreme or moderate quartiles is qualitatively different depending upon property type, location, or time period argues strongly against the existence of linear multifactor market models of UK commercial real estate and questions their applicability, as has already been done in the case of the US and Australia.

To identify the economic forces and mechanisms that produce the results observed in this study, agency-related concepts and behavioral finance models should provide fertile fields for future research. Additionally, extensions of this research and a better understanding of the forces that give rise to the patterns observed may likely lead to rewarding operational prescriptions such as programs of systematically identifying and culling underperforming assets from portfolios in order to improve overall portfolio performance. 


\section{Notes}

1. IPD have since adopted a different definition of coverage, stating that the UK annual index represents $45 \%$ of the total commercial property investment market.

2. 'Retail' includes shop, retail warehouse and shopping centre investments. Industrial property includes distribution warehouses in addition to industrial estates and individual units. Such classification does raise the question of the treatment of mixed use properties. These are either allocated to a particular category according to the dominant use or, for certain schemes, split into separate records reflecting the different valuation units / elements. The exact treatment depends on the contributing investor.

3. While more fine-grained divisions such as deciles might have been used, quartile divisions are the minimum necessary to distinguish differences in a distribution of returns that may be skewed. Furthermore, the quartile divisions allow comparability with earlier work in the US and Australia.

4. This may help explain the apparent contradiction between results found here and by other studies in the literature review, and research that condemns trend-chasing behaviour by investors (e.g. Mei and Saunders, 1997).

5. Institutional-grade commercial real estate return distributions are also remarkably similar across the UK, US, and Australian markets. In all these countries, crosssectional annual returns were found to be distinctly non-normal. Real estate investment risk is heteroskedastic, but the Characteristic Exponent "alpha” of the investment risk function is nearly constant across time although differences among property types are evident. In particular, the Characteristic Exponent, which for Gaussian normal distributions has a value of 2.000 , has been estimated to be 1.448 (0.004 standard error) in the UK, 1.434 (0.011 standard error) in the US, and 1.477 (0.038 standard error) in Australia. See Young and Graff (1995); Young (2005); 
Graff, Harrington, and Young (1997); and Young, Lee, and Devaney (2006) for empirical support and analysis far too lengthy to consider here. 


\section{References}

Baum, A., Crosby, N., Gallimore, P., Gray, A. and McAllister, P. (2000) The Influence of Valuers and Valuations on the Workings of the Commercial Property Investment Market. Investment Property Forum / RICS Research Foundation / Jones Lang LaSalle, London.

BPF / IPD. (2004) BPF IPD Annual Lease Review 2004, British Property Federation, London.

Brown, G.R. and Matysiak, G.A. (2000) Real Estate Investment: A Capital Market Approach, Financial Times Prentice Hall, Harlow.

CBRE. (2005) Global Market Rents August 2005, CB Richard Ellis, Accessed at www.cbre.com.

Crosby, N. (1990) The Valuation of Freehold Reversionary Property Investments in UK Practice, Research Report for the RICS Education Trust, Department of Estate Management, Oxford Polytechnic (Oxford Brookes University).

Crosby, N., Hughes, C. and Murdoch, S. (2005) Monitoring the 2002 Code of Practice for Commercial Leases, Office of the Deputy Prime Minister, London.

Crosby, N., Lavers, A. and Murdoch, J. (1998) Property valuation variation and the margin of Error in the UK, Journal of Property Research, Vol. 15 No. 4, pp. 305-330.

Diaz III, J. (1990a) How Appraisers do their Work: A Test of the Appraisal Process and the Development of a Descriptive Model, Journal of Real Estate Research, Vol. 5 No. 1, pp. 115.

Diaz III, J. (1990b) The Process of Selecting Comparable Sales, The Appraisal Journal, Vol. 58 No. 4, pp. 533-540.

Diaz III, J. (1997) An Investigation into the Impact of Previous Expert Value Estimates on Appraisal Judgment, Journal of Real Estate Research, Vol. 3 No. 1, pp. 157-66.

This article is (c) Emerald Group Publishing and permission has been granted for this version to appear here (http://centaur.reading.ac.uk/). Emerald does not grant permission for this article to be further copied / distributed or hosted elsewhere without the express permission from Emerald Group Publishing Limited. 
Diaz III, J. and Wolverton, M.L. (1998) A Longitudinal Examination of the Appraisal Smoothing Process, Real Estate Economics, Vol. 26 No. 2, pp. 349-356.

Graff, R.A., Harrington, A., and Young, M.S. (1997) The Shape of Australian Real Estate Return Distributions and Comparisons to the United States, Journal of Real Estate Research, Vol. 14 No. 3, pp. 291-308.

Graff, R.A., Harrington, A. and Young, M.S. (1999) Serial Persistence in Disaggregated Australian Real Estate Returns, Journal of Real Estate Portfolio Management, Vol. 5 No. 2, pp. 113-127.

Graff, R.A. and Webb, J.R. (1997) Agency Costs and Inefficiency in Commercial Real estate, Journal of Real Estate Portfolio Management, Vol. 3 No. 1, pp. 19-36.

Graff, R.A. and Young, M.S. (1997) Serial Persistence in Equity REIT Returns, Journal of Real Estate Research, Vol. 14 No. 3, pp. 183-214.

Graff, R.A. and Young, M.S. (1999) The Magnitude of Random Appraisal Error in Commercial Real Estate Valuation, Journal of Real Estate Research, Vol. 17 No. 1/2, pp. 33-54.

Grossman, S.J. and Stiglitz, J.E. (1976) Information and Competitive Price Systems, American Economic Review, Vol. 66, No. 2, pp. 246-253.

IPD (2003) IPD UK Annual Index, Investment Property Databank Ltd., London.

Lee, S.L. and Ward, C.W.R. (2001) Persistence of UK Real Estate Returns: A Markov Chain Analysis, Journal of Asset Management, Vol. 1 No. 3, pp. 279-291.

Marcato, G. and Key, T. (2005), Direct Investment in Real Estate: Momentum Profits and their Robustness to Trading Costs, Journal of Portfolio Management, Vol 32, Sept 2005, pp. 5569. 
Mei, J. and Saunders A. (1997). Have US Financial Institutions' Real Estate Investments Exhibited “Trend-Chasing” Behavior? The Review of Economics and Statistics, Vol. 79 No. 2, pp. 248-258.

Quan, D. and Quigley, J. (1989) Inferring an Investment Return Series for Real Estate from Observations on Sales, AREUEA Journal, Vol. 17 No. 2, pp. 218-230.

Quan, D. and Quigley, J. (1991) Price Formation and the Appraisal Function in Real Estate market, Journal of Real Estate Finance and Economics, Vol. 4 No. 2, pp. 127-146.

Royal Institution of Chartered Surveyors (2002) Property Valuation - The Carsberg Report, RICS, London.

Royal Institution of Chartered Surveyors (2003) RICS Appraisal and Valuation Standards (The Red Book), $5^{\text {th }}$ edition, RICS, London.

Young, M.S. (2005) Non-Normal Real Estate Return Distributions by Property Type in the U.S., paper presented at the 2005 Annual Meeting of the American Real Estate Society, Santa Fe, New Mexico, USA.

Young, M.S. and Graff, R.A. (1995) Real Estate Is Not Normal: A Fresh Look at Real Estate Return Distributions, Journal of Real Estate Finance and Economics, Vol. 10 No. 3, pp. 225259.

Young, M.S. and Graff, R.A. (1996) Systematic Behavior in Real Estate Investment Risk: Performance Persistence in NCREIF Returns, Journal of Real Estate Research, Vol. 12 No. 3, pp. 369-381.

Young, M.S. and Graff, R.A. (1997) Performance Persistence in Equity Real Estate Returns, Real Estate Finance, Vol. 14 No. 1, pp. 37-42.

Young, M.S., Lee, S.L., and Devaney, S.P. (2006) Non-Normal Real Estate Return Distributions by Property Type in the UK, Journal of Property Research. Vol. 23 No. 2, pp. 109-133.

This article is $\odot$ Emerald Group Publishing and permission has been granted for this version to appear here (http://centaur.reading.ac.uk/). Emerald does not grant permission for this article to be further copied / distributed or hosted elsewhere without the express permission from Emerald Group Publishing Limited. 
Table 1

Number of Return Observations by Year, Property Type, and Region in the IPD Database for Properties with at Least Two Observations, 1981 to 2002

\begin{tabular}{rrrrrrrr} 
Year & All & Retail & Office & Industrial & London & SoouthEast & RestofUK \\
\hline 1981 & 8,990 & 4,572 & 2,746 & 1,672 & 2,930 & 2,247 & 3,813 \\
1982 & 9,953 & 4,993 & 3,047 & 1,913 & 3,199 & 2,531 & 4,223 \\
1983 & 9,958 & 4,909 & 3,102 & 1,947 & 3,119 & 2,581 & 4,258 \\
1984 & 10,173 & 5,036 & 3,167 & 1,970 & 3,087 & 2,697 & 4,389 \\
1985 & 10,307 & 5,168 & 3,221 & 1,918 & 3,029 & 2,811 & 4,467 \\
& & & & & & & \\
1986 & 10,529 & 5,337 & 3,303 & 1,889 & 2,990 & 2,980 & 4,559 \\
1987 & 10,130 & 5,319 & 3,117 & 1,694 & 2,794 & 2,901 & 4,435 \\
1988 & 9,837 & 5,339 & 2,949 & 1,549 & 2,661 & 2,952 & 4,224 \\
1989 & 9,967 & 5,465 & 2,971 & 1,531 & 2,643 & 3,106 & 4,218 \\
1990 & 10,328 & 5,591 & 3,108 & 1,629 & 2,641 & 3,286 & 4,401 \\
1991 & 10,652 & 5,680 & 3,268 & 1,704 & 2,627 & 3,482 & 4,543 \\
1992 & 10,955 & 5,777 & 3,318 & 1,860 & 2,641 & 3,640 & 4,674 \\
1993 & 10,623 & 5,578 & 3,218 & 1,827 & 2,539 & 3,513 & 4,571 \\
1994 & 10,383 & 5,503 & 3,099 & 1,781 & 2,469 & 3,353 & 4,561 \\
1995 & 11,393 & 6,093 & 3,337 & 1,963 & 2,515 & 3,697 & 5,181 \\
1996 & 10,960 & 5,938 & 3,148 & 1,874 & 2,363 & 3,537 & 5,060 \\
1997 & 10,100 & 5,539 & 2,796 & 1,765 & 2,175 & 3,190 & 4,735 \\
1998 & 9,905 & 5,459 & 2,618 & 1,828 & 2,135 & 3,067 & 4,703 \\
1999 & 9,163 & 4,996 & 2,407 & 1,760 & 2,077 & 2,771 & 4,315 \\
2000 & 8,421 & 4,523 & 2,197 & 1,701 & 1,937 & 2,540 & 3,944 \\
& & & & & & & \\
2001 & 7,546 & 3,665 & 2,107 & 1,774 & 1,771 & 2,329 & 3,446 \\
2002 & 6,485 & 3,047 & 1,839 & 1,599 & 1,589 & 1,998 & 2,898 \\
Totals & 216,758 & 113,527 & 64,083 & 39,148 & 55,931 & 65,209 & 95,618
\end{tabular}


Table 2

Annual Return Persistence, 1981 to 2002

\section{Panel A: All Properties}

\begin{tabular}{|c|c|c|c|c|c|c|c|c|c|}
\hline $\begin{array}{l}\text { Length } \\
\text { of Run }\end{array}$ & $\begin{array}{c}\text { No. of } \\
\text { Samples }\end{array}$ & $\begin{array}{c}\text { No. of } \\
\text { Successes }\end{array}$ & $\begin{array}{c}\% \text { of } \\
\text { Successes }\end{array}$ & $\begin{array}{r}95 \% \text { Conf. } \\
\text { Interval } \\
\end{array}$ & $\begin{array}{l}\text { Length } \\
\text { of Run }\end{array}$ & $\begin{array}{c}\text { No. of } \\
\text { Samples }\end{array}$ & $\begin{array}{c}\text { No. of } \\
\text { Successes }\end{array}$ & $\begin{array}{c}\% \text { of } \\
\text { Successes }\end{array}$ & $\begin{array}{r}95 \% \text { Conf. } \\
\text { Interval }\end{array}$ \\
\hline \multicolumn{5}{|c|}{ 1st Quartile: } & \multicolumn{5}{|c|}{ 2nd Quartile: } \\
\hline 1 & 46,871 & 16,118 & $34.4 * * *$ & $(24.6,25.4)$ & 1 & 47,388 & 13,619 & $28.7 * * *$ & $(24.6,25.4)$ \\
\hline 2 & 13,795 & 5,430 & $39.4 * * *$ & $(24.3,25.7)$ & 2 & 11,764 & 3,617 & $30.7^{* * *}$ & $(24.2,25.8)$ \\
\hline 3 & 4,698 & 1,974 & $42.0 * * *$ & $(23.8,26.2)$ & 3 & 3,139 & 980 & 31.2 *** & $(23.5,26.5)$ \\
\hline 4 & 1,717 & 713 & $41.5 * * *$ & $(23.0,27.1)$ & 4 & 864 & 261 & $30.2 *$ & $(22.2,27.9)$ \\
\hline \multicolumn{5}{|c|}{ 4th Quartile: } & \multicolumn{5}{|c|}{ 3rd Quartile: } \\
\hline 1 & 45,261 & 16,819 & $37.2 * * *$ & $(24.6,25.4)$ & 1 & 47,238 & 13,222 & $28.0 * * *$ & $(24.6,25.4)$ \\
\hline 2 & 13,371 & 5,359 & $40.1^{* * *}$ & $(24.3,25.7)$ & 2 & 11,302 & 3,296 & $29.2 * * *$ & $(24.2,25.8)$ \\
\hline 3 & 4,199 & 1,682 & $40.1^{* * *}$ & $(23.7,26.3)$ & 3 & 2,835 & 854 & $30.1^{* * *}$ & $(23.4,26.6)$ \\
\hline 4 & 1,258 & 500 & $39.7 * * *$ & $(22.6,27.4)$ & 4 & 717 & 224 & $31.2 *$ & $(21.9,28.2)$ \\
\hline \multicolumn{5}{|c|}{ 1st \& 4th Combined Quartiles: } & \multicolumn{5}{|c|}{ 2nd \& 3rd Combined Quartiles: } \\
\hline 1 & 92,132 & 32,937 & $35.7 * * *$ & $(24.7,25.3)$ & 1 & 94,626 & 26,841 & $28.4 * * *$ & $(24.7,25.3)$ \\
\hline 2 & 27,166 & 10,789 & $39.7 * * *$ & $(24.5,25.5)$ & 2 & 23,066 & 6,913 & 30.0 *** & $(24.4,25.6)$ \\
\hline 3 & 8,897 & 3,656 & $41.1^{* * *}$ & $(24.1,25.8)$ & 3 & 5,974 & 1,834 & $30.7 * * *$ & $(23.9,26.1)$ \\
\hline 4 & 2,975 & 1,213 & $40.8 * * *$ & $(23.5,26.6)$ & 4 & 1,581 & 485 & $30.7 * *$ & $(22.9,27.2)$ \\
\hline
\end{tabular}

Panel B: Office Properties

\begin{tabular}{|c|c|c|c|c|c|c|c|c|c|}
\hline $\begin{array}{l}\text { Length } \\
\text { of Run }\end{array}$ & $\begin{array}{c}\text { No. of } \\
\text { Samples }\end{array}$ & $\begin{array}{c}\text { No. of } \\
\text { Successes }\end{array}$ & $\begin{array}{c}\% \text { of } \\
\text { Successes }\end{array}$ & $\begin{array}{r}\text { 95\% Conf. } \\
\text { Interval } \\
\end{array}$ & $\begin{array}{l}\text { Length } \\
\text { of Run }\end{array}$ & $\begin{array}{c}\text { No. of } \\
\text { Samples }\end{array}$ & $\begin{array}{c}\text { No. of } \\
\text { Successes }\end{array}$ & $\begin{array}{c}\% \text { of } \\
\text { Successes }\end{array}$ & $\begin{array}{r}95 \% \text { Conf. } \\
\text { Interval } \\
\end{array}$ \\
\hline \multicolumn{5}{|c|}{ 1st Quartile: } & \multicolumn{5}{|c|}{ 2nd Quartile: } \\
\hline 1 & 12,907 & 4,307 & 33.4 *** & $(24.3,25.8)$ & 1 & 13,198 & 3,643 & $27.6 * * *$ & $(24.3,25.7)$ \\
\hline 2 & 3,648 & 1,364 & $37.4^{* * *}$ & $(23.6,26.4)$ & 2 & 3,162 & 915 & $28.9 * *$ & $(23.5,26.5)$ \\
\hline 3 & 1,156 & 473 & $40.9 * * *$ & $(22.5,27.5)$ & 3 & 792 & 244 & 30.8 * & $(22.0,28.1)$ \\
\hline 4 & 408 & 172 & $42.2 * * *$ & $(20.9,29.3)$ & 4 & 214 & 56 & 26.2 & $(19.4,31.0)$ \\
\hline \multicolumn{5}{|c|}{ 4th Quartile: } & \multicolumn{5}{|c|}{ 3rd Quartile: } \\
\hline 1 & 15,146 & 6,342 & $41.9 * * *$ & $(24.3,25.7)$ & 1 & 13,909 & 3,886 & $27.9 * * *$ & $(24.3,25.7)$ \\
\hline 2 & 5,089 & 2,232 & $43.9 * * *$ & $(23.8,26.2)$ & 2 & 3,350 & 1,003 & $29.9 * * *$ & $(23.5,26.5)$ \\
\hline 3 & 1,788 & 759 & $42.9 * * *$ & $(23.0,27.0)$ & 3 & 869 & 253 & $29.1 *$ & $(22.2,27.9)$ \\
\hline 4 & 579 & 244 & $42.1 * * *$ & $(21.6,28.6)$ & 4 & 214 & 63 & 29.4 & $(19.4,31.0)$ \\
\hline \multicolumn{5}{|c|}{ 1st \& 4th Combined Quartiles: } & \multicolumn{5}{|c|}{ 2nd \& 3rd Combined Quartiles: } \\
\hline 1 & 28,053 & 10,649 & 38.0 *** & $(24.5,25.5)$ & 1 & 27,107 & 7,529 & $27.8 * * *$ & $(24.5,25.5)$ \\
\hline 2 & 8,737 & 3,596 & $41.2 * * *$ & $(24.1,25.9)$ & 2 & 6,512 & 1,918 & $29.5 * * *$ & $(24.0,26.1)$ \\
\hline 3 & 2,944 & 1,232 & $41.8 * * *$ & $(23.5,26.6)$ & 3 & 1,661 & 497 & $29.9 * *$ & $(22.9,27.1)$ \\
\hline 4 & 987 & 416 & $42.1^{* * *}$ & $(22.3,27.8)$ & 4 & 428 & 117 & 27.8 & $(21.0,29.2)$ \\
\hline
\end{tabular}

This article is () Emerald Group Publishing and permission has been granted for this version to appear here (http://centaur.reading.ac.uk/). Emerald does not grant permission for this article to be further copied / distributed or hosted elsewhere without the express permission from Emerald Group Publishing Limited. 
Table 2 (continued)

Annual Return Persistence, 1981 to 2002

\section{Panel C: Retail Properties}

\begin{tabular}{|c|c|c|c|c|c|c|c|c|c|}
\hline $\begin{array}{l}\text { Length } \\
\text { of Run }\end{array}$ & $\begin{array}{c}\text { No. of } \\
\text { Samples }\end{array}$ & $\begin{array}{c}\text { No. of } \\
\text { Successes }\end{array}$ & $\begin{array}{c}\% \text { of } \\
\text { Successes }\end{array}$ & $\begin{array}{r}\text { 95\% Conf. } \\
\text { Interval } \\
\end{array}$ & $\begin{array}{l}\text { Length } \\
\text { of Run }\end{array}$ & $\begin{array}{c}\text { No. of } \\
\text { Samples }\end{array}$ & $\begin{array}{c}\text { No. of } \\
\text { Successes }\end{array}$ & $\begin{array}{c}\% \text { of } \\
\text { Successes }\end{array}$ & $\begin{array}{r}95 \% \text { Conf. } \\
\text { Interval }\end{array}$ \\
\hline \multicolumn{5}{|c|}{ 1st Quartile: } & \multicolumn{5}{|c|}{ 2nd Quartile: } \\
\hline 1 & 24,828 & 8,359 & $33.7^{* * *}$ & $(24.5,25.5)$ & 1 & 24,754 & 6,972 & $28.2 * * *$ & $(24.5,25.5)$ \\
\hline 2 & 7,216 & 2,826 & $39.2 * * *$ & $(24.0,26.0)$ & 2 & 6,122 & 1,879 & $30.7 * * *$ & $(23.9,26.1)$ \\
\hline 3 & 2,493 & 1,058 & $42.4 * * *$ & $(23.3,26.7)$ & 3 & 1,676 & 512 & $30.5 * *$ & $(23.0,27.1)$ \\
\hline 4 & 929 & 386 & $41.6 * * *$ & $(22.3,27.8)$ & 4 & 461 & 192 & 28.9 & $(21.2,29.1)$ \\
\hline \multicolumn{5}{|c|}{ 4th Quartile: } & \multicolumn{5}{|c|}{ 3rd Quartile: } \\
\hline 1 & 23,172 & 8,016 & $34.6 * * *$ & $(24.4,25.6)$ & 1 & 25,496 & 7,224 & $28.3 * * *$ & $(24.5,25.5)$ \\
\hline 2 & 6,237 & 2,301 & $36.9 * * *$ & $(23.9,26.0)$ & 2 & 6,206 & 1,815 & $29.2 * * *$ & $(23.9,26.1)$ \\
\hline 3 & 1,733 & 660 & $38.1 * *$ & $(23.0,27.1)$ & 3 & 1,559 & 487 & $31.2 * * *$ & $(22.9,27.2)$ \\
\hline 4 & 472 & 192 & $40.7 * * *$ & $(21.2,29.0)$ & 4 & 411 & 135 & $32.8 *$ & $(20.9,29.3)$ \\
\hline \multicolumn{5}{|c|}{ 1st \& 4th Combined Quartiles: } & \multicolumn{5}{|c|}{ 2nd \& 3rd Combined Quartiles: } \\
\hline 1 & 48,000 & 16,375 & $34.1 * * *$ & $(24.6,25.4)$ & 1 & 50,250 & 14,196 & $28.3 * * *$ & $(24.6,25.4)$ \\
\hline 2 & 13,453 & 5,127 & $38.1 * * *$ & $(24.3,25.7)$ & 2 & 12,328 & 3,694 & $30.0 * * *$ & $(24.2,25.8)$ \\
\hline 3 & 4,226 & 1,718 & $40.7 * * *$ & $(23.8,26.3)$ & 3 & 3,235 & 999 & $30.90 * * *$ & $(23.5,26.5)$ \\
\hline 4 & 1,401 & 578 & $41.3 * * *$ & $(22.8,27.3)$ & 4 & 872 & 268 & $30.7 *$ & $(22.2,27.9)$ \\
\hline
\end{tabular}

\section{Panel D: Industrial Properties}

\begin{tabular}{|c|c|c|c|c|c|c|c|c|c|}
\hline $\begin{array}{l}\text { Length } \\
\text { of Run }\end{array}$ & $\begin{array}{c}\text { No. of } \\
\text { Samples }\end{array}$ & $\begin{array}{c}\text { No. of } \\
\text { Successes }\end{array}$ & $\begin{array}{c}\% \text { of } \\
\text { Successes }\end{array}$ & $\begin{array}{r}\text { 95\% Conf. } \\
\text { Interval } \\
\end{array}$ & $\begin{array}{l}\text { Length } \\
\text { of Run }\end{array}$ & $\begin{array}{c}\text { No. of } \\
\text { Samples }\end{array}$ & $\begin{array}{c}\text { No. of } \\
\text { Successes }\end{array}$ & $\begin{array}{c}\% \text { of } \\
\text { Successes }\end{array}$ & $\begin{array}{r}95 \% \text { Conf. } \\
\text { Interval } \\
\end{array}$ \\
\hline \multicolumn{5}{|c|}{ 1st Quartile: } & \multicolumn{5}{|c|}{ 2nd Quartile: } \\
\hline 1 & 9,136 & 3,452 & $37.8 * * *$ & $(24.1,25.9)$ & 1 & 9,436 & 3,004 & $31.8 * * *$ & $(24.1,25.9)$ \\
\hline 2 & 2,931 & 1,240 & $42.3 * * *$ & $(23.4,26.6)$ & 2 & 2,480 & 823 & $33.2 * * *$ & $(23.3,26.7)$ \\
\hline 3 & 1,049 & 443 & $42.2 * * *$ & $(22.4,27.7)$ & 3 & 671 & 224 & $33.4 * *$ & $(21.8,28.4)$ \\
\hline 4 & 380 & 155 & $40.8 * * *$ & $(20.8,29.5)$ & 4 & 189 & 72 & $38.1 * *$ & $(19.1,31.4)$ \\
\hline \multicolumn{5}{|c|}{ 4th Quartile: } & \multicolumn{5}{|c|}{ 3rd Quartile: } \\
\hline 1 & 6,943 & 2,461 & $35.4 * * *$ & $(24.0,26.0)$ & 1 & 7,833 & 2,112 & $27.0 * *$ & $(24.0,26.0)$ \\
\hline 2 & 2,045 & 826 & $40.4 * * *$ & $(23.1,26.9)$ & 2 & 1,746 & 478 & $27.4 *$ & $(23.0,27.1)$ \\
\hline 3 & 678 & 263 & $38.8 * * *$ & $(21.8,28.3)$ & 3 & 407 & 114 & 28.0 & $(20.9,29.3)$ \\
\hline 4 & 207 & 64 & 30.9 & $(19.3,31.1)$ & 4 & 92 & 26 & 28.3 & $(16.7,34.4)$ \\
\hline \multicolumn{5}{|c|}{ 1st \& 4th Combined Quartiles: } & \multicolumn{5}{|c|}{ 2nd \& 3rd Combined Quartiles: } \\
\hline 1 & 16,079 & 5,913 & $36.8 * * *$ & $(24.3,25.7)$ & 1 & 17,269 & 5,116 & $29.6 * * *$ & $(24.4,25.6)$ \\
\hline 2 & 4,976 & 2,066 & $41.5 * * *$ & $(23.8,26.2)$ & 2 & 4,226 & 1,301 & $30.8 * * *$ & $(23.7,26.3)$ \\
\hline 3 & 1,727 & 706 & $40.9 * * *$ & $(23.0,27.1)$ & 3 & 1,078 & 338 & $31.4 * *$ & $(22.5,27.6)$ \\
\hline 4 & 587 & 219 & $37.3 * * *$ & $(21.6,28.6)$ & 4 & 281 & 98 & $34.9 *$ & $(20.1,30.2)$ \\
\hline
\end{tabular}

This article is (c) Emerald Group Publishing and permission has been granted for this version to appear here (http://centaur.reading.ac.uk/). Emerald does not grant permission for this article to be further copied / distributed or hosted elsewhere without the express permission from Emerald Group Publishing Limited. 
Table 2 (continued)

Annual Return Persistence, 1981 to 2002

Panel E: London

\begin{tabular}{|c|c|c|c|c|c|c|c|c|c|}
\hline $\begin{array}{l}\text { Length } \\
\text { of Run }\end{array}$ & $\begin{array}{c}\text { No. of } \\
\text { Samples }\end{array}$ & $\begin{array}{c}\text { No. of } \\
\text { Successes }\end{array}$ & $\begin{array}{c}\% \text { of } \\
\text { Successes } \\
\end{array}$ & $\begin{array}{r}95 \% \text { Conf. } \\
\text { Interval } \\
\end{array}$ & $\begin{array}{l}\text { Length } \\
\text { of Run }\end{array}$ & $\begin{array}{c}\text { No. of } \\
\text { Samples }\end{array}$ & $\begin{array}{c}\text { No. of } \\
\text { Successes }\end{array}$ & $\begin{array}{c}\% \text { of } \\
\text { Successes }\end{array}$ & $\begin{array}{r}95 \% \text { Conf } \\
\text { Interval } \\
\end{array}$ \\
\hline \multicolumn{5}{|c|}{ 1st Quartile: } & \multicolumn{5}{|c|}{ 2nd Quartile: } \\
\hline 1 & 13,426 & 5,097 & $38.0 * * *$ & $(24.3,25.7)$ & 1 & 11,825 & 3,341 & $28.3 * * *$ & $(24.5,25.5)$ \\
\hline 2 & 4,342 & 1,811 & $41.7 * * *$ & $(23.7,26.3)$ & 2 & 2,913 & 869 & $29.8 * * *$ & $(23.4,26.6)$ \\
\hline 3 & 1,541 & 681 & $44.2 * * *$ & $(22.9,27.2)$ & 3 & 760 & 233 & 30.7 * & $(22.0,28.1)$ \\
\hline 4 & 588 & 259 & $44.0 * * *$ & $(21.6,28.6)$ & 4 & 209 & 61 & 29.2 & $(19.4,31.1)$ \\
\hline \multicolumn{5}{|c|}{ 4th Quartile: } & \multicolumn{5}{|c|}{ 3rd Quartile: } \\
\hline 1 & 11,788 & 4,620 & $39.2 * * *$ & $(24.2,25.8)$ & 1 & 11,273 & 2,995 & $26.6 *$ & $(24.2,25.8)$ \\
\hline 2 & 3,778 & 1,589 & $42.1 * * *$ & $(23.6,26.4)$ & 2 & 2,607 & 744 & $28.5 * *$ & $(23.4,26.7)$ \\
\hline 3 & 1,281 & 528 & $41.2 * * *$ & $(22.7,27.4)$ & 3 & 655 & 215 & $32.8 * *$ & $(21.8,28.4)$ \\
\hline 4 & 401 & 154 & $38.4 * * *$ & $(20.9,29.4)$ & 4 & 183 & 56 & 30.6 & $(19.0,31.5)$ \\
\hline \multicolumn{5}{|c|}{ 1st \& 4th Combined Quartiles: } & \multicolumn{5}{|c|}{ 2nd \& 3rd Combined Quartiles: } \\
\hline 1 & 25,214 & 9,717 & $38.5 * * *$ & $(24.5,25.5)$ & 1 & 23,098 & 6,336 & $27.4 * * *$ & $(24.4,25.6)$ \\
\hline 2 & 8,120 & 3,400 & $41.9 * * *$ & $(24.1,25.9)$ & 2 & 5,520 & 1,613 & $29.2 * * *$ & $(23.9,26.2)$ \\
\hline 3 & 2,822 & 1,209 & $42.8 * * *$ & $(23.4,26.6)$ & 3 & 1,415 & 448 & $31.7 * * *$ & $(22.8,27.3)$ \\
\hline 4 & 989 & 413 & $41.8 * * *$ & $(22.4,27.7)$ & 4 & 392 & 117 & $29.8 *$ & $(20.8,29.4)$ \\
\hline
\end{tabular}

Panel F: South East

\begin{tabular}{|c|c|c|c|c|c|c|c|c|c|}
\hline $\begin{array}{l}\text { Length } \\
\text { of Run }\end{array}$ & $\begin{array}{c}\text { No. of } \\
\text { Samples }\end{array}$ & $\begin{array}{c}\text { No. of } \\
\text { Successes }\end{array}$ & $\begin{array}{c}\% \text { of } \\
\text { Successes }\end{array}$ & $\begin{array}{r}\text { 95\% Conf. } \\
\text { Interval }\end{array}$ & $\begin{array}{l}\text { Length } \\
\text { of Run }\end{array}$ & $\begin{array}{c}\text { No. of } \\
\text { Samples }\end{array}$ & $\begin{array}{c}\text { No. of } \\
\text { Successes }\end{array}$ & $\begin{array}{c}\% \text { of } \\
\text { Successes }\end{array}$ & $\begin{array}{l}95 \% \text { Conf. } \\
\text { Interval }\end{array}$ \\
\hline \multicolumn{5}{|c|}{ 1st Quartile: } & \multicolumn{5}{|c|}{ 2nd Quartile: } \\
\hline 1 & 12,847 & 3,998 & 31.1 *** & $(24.3,25.8)$ & 1 & 14,517 & 4,138 & $28.5 * * *$ & $(24.3,25.7)$ \\
\hline 2 & 3,395 & 1,268 & $37.3 * * *$ & $(23.6,26.5)$ & 2 & 3,590 & 1,097 & 30.6 *** & $(23.6,26.4)$ \\
\hline 3 & 1,088 & 433 & $39.8 * * *$ & $(22.5,27.6)$ & 3 & 951 & 292 & $30.7 * *$ & $(22.3,27.8)$ \\
\hline 4 & 376 & 144 & 38.3 *** & $(20.8,29.5)$ & 4 & 254 & 82 & $32.3 *$ & $(19.9,30.5)$ \\
\hline \multicolumn{5}{|c|}{ 4th Quartile: } & \multicolumn{5}{|c|}{ 3rd Quartile: } \\
\hline 1 & 13,945 & 5,130 & $36.8 * * *$ & $(24.3,25.7)$ & 1 & 14,887 & 4,285 & $28.8 * * *$ & $(24.3,25.7)$ \\
\hline 2 & 4,041 & 1,550 & $38.4 * * *$ & $(23.7,26.3)$ & 2 & 3,633 & 1,082 & $29.8 * * *$ & $(23.6,26.4)$ \\
\hline 3 & 1,220 & 454 & $37.2 * * *$ & $(22.6,27.5)$ & 3 & 925 & 267 & $28.9 * *$ & $(22.3,27.8)$ \\
\hline 4 & 338 & 129 & $38.2 * * *$ & $(20.5,29.8)$ & 4 & 219 & 66 & 30.1 & $(19.5,31.0)$ \\
\hline \multicolumn{5}{|c|}{ 1st \& 4th Combined Quartiles: } & \multicolumn{5}{|c|}{ 2nd \& 3rd Combined Quartiles: } \\
\hline 1 & 26,792 & 9,128 & $34.1 * * *$ & $(24.5,25.5)$ & 1 & 29,404 & 8,423 & $28.6 * * *$ & $(24.5,25.5)$ \\
\hline 2 & 7,436 & 2,818 & $37.9 * * *$ & $(24.0,26.0)$ & 2 & 7,223 & 2,179 & $30.2 * * *$ & $(24.0,26.0)$ \\
\hline 3 & 2,308 & 887 & $38.4^{* * *}$ & $(23.3,26.8)$ & 3 & 1,876 & 559 & $29.8 * *$ & $(23.1,27.0)$ \\
\hline 4 & 714 & 273 & 38.2 *** & $(21.9,28.2)$ & 4 & 473 & 148 & $31.3 *$ & $(21.2,29.0)$ \\
\hline
\end{tabular}

This article is $\odot$ Emerald Group Publishing and permission has been granted for this version to appear here (http://centaur.reading.ac.uk/). Emerald does not grant permission for this article to be further copied / distributed or hosted elsewhere without the express permission from Emerald Group Publishing Limited. 
Table 2 (continued)

Annual Return Persistence, 1981 to 2002

\section{Panel G: Rest of United Kingdom}

\begin{tabular}{|c|c|c|c|c|c|c|c|c|c|}
\hline $\begin{array}{l}\text { Length } \\
\text { of Run }\end{array}$ & $\begin{array}{c}\text { No. of } \\
\text { Samples }\end{array}$ & $\begin{array}{c}\text { No. of } \\
\text { Successes }\end{array}$ & $\begin{array}{c}\% \text { of } \\
\text { Successes }\end{array}$ & $\begin{array}{r}95 \% \text { Conf. } \\
\text { Interval } \\
\end{array}$ & $\begin{array}{l}\text { Length } \\
\text { of Run }\end{array}$ & $\begin{array}{c}\text { No. of } \\
\text { Samples }\end{array}$ & $\begin{array}{c}\text { No. of } \\
\text { Successes }\end{array}$ & $\begin{array}{c}\% \text { of } \\
\text { Successes }\end{array}$ & $\begin{array}{r}95 \% \text { Conf. } \\
\text { Interval }\end{array}$ \\
\hline \multicolumn{5}{|c|}{ 1st Quartile: } & \multicolumn{5}{|c|}{ 2nd Quartile: } \\
\hline 1 & 20,598 & 7,023 & $34.1 * * *$ & $(24.4,25.6)$ & 1 & 21,046 & 6,140 & $29.2 * * *$ & $(24.4,25.6)$ \\
\hline 2 & 6,058 & 2,351 & 38.8 *** & $(23.9,26.1)$ & 2 & 5,261 & 1,651 & $31.4^{* * *}$ & $(23.8,26.2)$ \\
\hline 3 & 2,069 & 860 & 41.6 *** & $(23.2,26.9)$ & 3 & 1,428 & 455 & $31.9 * * *$ & $(22.8,27.3)$ \\
\hline 4 & 753 & 310 & $41.2 * * *$ & $(22.0,28.2)$ & 4 & 401 & 118 & $29.4 *$ & $(20.9,29.4)$ \\
\hline \multicolumn{5}{|c|}{ 4th Quartile: } & \multicolumn{5}{|c|}{ 3rd Quartile: } \\
\hline 1 & 19,528 & 7,069 & $36.2 * * *$ & $(24.4,25.6)$ & 1 & 21,078 & 5,942 & $28.2 * * *$ & $(24.4,25.6)$ \\
\hline 2 & 5,552 & 2,220 & $40.0 * * *$ & $(23.9,26.1)$ & 2 & 5,062 & 1,470 & $29.0 * * *$ & $(23.8,26.2)$ \\
\hline 3 & 1,698 & 700 & $41.2 * * *$ & $(23.0,27.1)$ & 3 & 1,255 & 372 & $29.6 *$ & $(22.6,27.4)$ \\
\hline 4 & 519 & 217 & $41.8 * * *$ & $(21.4,28.8)$ & 4 & 315 & 102 & $32.4 *$ & $(20.4,29.9)$ \\
\hline \multicolumn{5}{|c|}{ 1st \& 4th Combined Quartiles: } & \multicolumn{5}{|c|}{ 2nd \& 3rd Combined Quartiles: } \\
\hline 1 & 40,126 & 14,092 & 35.1 *** & $(24.6,25.4)$ & 1 & 42,124 & 12,082 & $28.7 * * *$ & $(24.6,25.4)$ \\
\hline 2 & 11,610 & 4,571 & $39.4^{* * *}$ & $(24.2,25.8)$ & 2 & 10,323 & 3,121 & 30.2 *** & $(24.2,25.8)$ \\
\hline 3 & 3,767 & 1,560 & $41.4 * * *$ & $(23.6,26.4)$ & 3 & 2,683 & 827 & $30.8 * * *$ & $(23.4,26.7)$ \\
\hline 4 & 1,272 & 527 & $41.4 * * *$ & $(22.7,27.4)$ & 4 & 716 & 220 & $30.7 *$ & $(21.9,28.2)$ \\
\hline
\end{tabular}

* $\quad$ Null hypothesis rejected at the $5 \%$ level of significance

$* * \quad$ Null hypothesis rejected at the $0.01 \%$ level of significance

*** Null hypothesis rejected at the $0.00001 \%$ level of significance

This article is (c) Emerald Group Publishing and permission has been granted for this version to appear here (http://centaur.reading.ac.uk/). Emerald does not grant permission for this article to be further copied / distributed or hosted elsewhere without the express permission from Emerald Group Publishing Limited. 
Table 3

Annual Return Persistence for Various Holding Periods

Panel A: 2- to 5-year Holding Period

\begin{tabular}{|c|c|c|c|c|c|c|c|c|c|}
\hline $\begin{array}{l}\text { Length } \\
\text { of Run }\end{array}$ & $\begin{array}{c}\text { No. of } \\
\text { Samples }\end{array}$ & $\begin{array}{c}\text { No. of } \\
\text { Successes }\end{array}$ & $\begin{array}{c}\% \text { of } \\
\text { Successes }\end{array}$ & $\begin{array}{r}95 \% \text { Conf. } \\
\text { Interval } \\
\end{array}$ & $\begin{array}{l}\text { Length } \\
\text { of Run }\end{array}$ & $\begin{array}{c}\text { No. of } \\
\text { Samples }\end{array}$ & $\begin{array}{c}\text { No. of } \\
\text { Successes }\end{array}$ & $\begin{array}{c}\% \text { of } \\
\text { Successes }\end{array}$ & $\begin{array}{r}95 \% \text { Conf. } \\
\text { Interval }\end{array}$ \\
\hline \multicolumn{5}{|c|}{ 1st Quartile: } & \multicolumn{5}{|c|}{ 2nd Quartile: } \\
\hline 1 & 3,865 & 1,158 & $30.0 * * *$ & $(23.6,26.4)$ & 1 & 4,450 & 1,190 & $26.7 *$ & $(23.7,26.3)$ \\
\hline 2 & 642 & 217 & $33.8 * *$ & $(21.7,28.4)$ & 2 & 707 & 192 & 27.2 & $(21.9,28.3)$ \\
\hline 3 & 88 & 31 & $35.2 *$ & $(16.5,34.6)$ & 3 & 88 & 24 & 27.3 & $(16.5,34.6)$ \\
\hline 4 & 11 & 4 & 36.4 & $(4.0,55.1)$ & 4 & 11 & 2 & 18.2 & $(4.0,55.1)$ \\
\hline \multicolumn{5}{|c|}{ 4th Quartile: } & \multicolumn{5}{|c|}{ 3rd Quartile: } \\
\hline 1 & 4,804 & 2,041 & $42.5 * * *$ & $(23.8,26.2)$ & 1 & 4,755 & 1,437 & $30.2 * * *$ & $(23.8,26.2)$ \\
\hline 2 & 1,068 & 483 & $45.2 * * *$ & $(22.4,27.6)$ & 2 & 833 & 251 & $30.1 *$ & $(22.1,28.0)$ \\
\hline 3 & 211 & 81 & $38.4 * *$ & $(19.4,31.1)$ & 3 & 127 & 50 & $39.4 *$ & $(17.9,32.9)$ \\
\hline 4 & 28 & 10 & 35.7 & $(10.7,42.8)$ & 4 & 24 & 9 & 37.5 & $(9.8,44.4)$ \\
\hline \multicolumn{5}{|c|}{ 1st \& 4th Combined Quartiles: } & \multicolumn{5}{|c|}{ 2nd \& 3rd Combined Quartiles: } \\
\hline 1 & 8,669 & 3,399 & $36.9 * * *$ & $(24.1,25.9)$ & 1 & 9,205 & 2,627 & $28.5 * * *$ & $(24.1,25.9)$ \\
\hline 2 & 1,710 & 700 & $40.9 * * *$ & $(23.0,27.1)$ & 2 & 1,540 & 443 & $28.8 *$ & $(22.9,27.2)$ \\
\hline 3 & 299 & 112 & $37.5 * *$ & $(20.3,30.1)$ & 3 & 215 & 74 & $34.4 *$ & $(19.4,31.0)$ \\
\hline 4 & 39 & 14 & 35.9 & $(12.7,39.9)$ & 4 & 35 & 11 & 31.4 & $(12.1,40.8)$ \\
\hline
\end{tabular}

Panel B: 6- to 10-year Holding Period

\begin{tabular}{|c|c|c|c|c|c|c|c|c|c|}
\hline $\begin{array}{l}\text { Length } \\
\text { of Run }\end{array}$ & $\begin{array}{l}\text { No. of } \\
\text { Samples }\end{array}$ & $\begin{array}{c}\text { No. of } \\
\text { Successes }\end{array}$ & $\begin{array}{c}\% \text { of } \\
\text { Successes }\end{array}$ & $\begin{array}{l}\text { 95\% Conf. } \\
\text { Interval }\end{array}$ & $\begin{array}{l}\text { Length } \\
\text { of Run }\end{array}$ & $\begin{array}{c}\text { No. of } \\
\text { Samples }\end{array}$ & $\begin{array}{c}\text { No. of } \\
\text { Successes }\end{array}$ & $\begin{array}{c}\% \text { of } \\
\text { Successes }\end{array}$ & $\begin{array}{l}\text { 95\% Conf. } \\
\text { Interval }\end{array}$ \\
\hline \multicolumn{5}{|c|}{ 1st Quartile: } & \multicolumn{5}{|c|}{ 2nd Quartile: } \\
\hline 1 & 7,109 & 2,137 & $30.1 * * *$ & $(24.0,26.0)$ & 1 & 8,164 & 2,325 & $28.5 * * *$ & $(24.1,25.9)$ \\
\hline 2 & 1,819 & 650 & $35.7 * * *$ & $(23.0,27.0)$ & 2 & 2,048 & 637 & $31.1 * * *$ & $(23.1,26.9)$ \\
\hline 3 & 530 & 206 & $38.9 * * *$ & $(21.4,28.8)$ & 3 & 560 & 166 & $29.6 *$ & $(21.5,28.7)$ \\
\hline 4 & 163 & 67 & $41.1 * *$ & $(18.7,32.0)$ & 4 & 142 & 37 & 26.1 & $(18.2,32.5)$ \\
\hline \multicolumn{5}{|c|}{ 4th Quartile: } & \multicolumn{5}{|c|}{ 3rd Quartile: } \\
\hline 1 & 8,154 & 3,145 & $38.6 * * *$ & $(24.1,25.9)$ & 1 & 8,694 & 2,515 & $28.9 * * *$ & $(24.1,25.9)$ \\
\hline 2 & 2,527 & 1,057 & $41.8 * * *$ & $(23.3,26.7)$ & 2 & 2,199 & 666 & $30.3 * * *$ & $(23.2,26.8)$ \\
\hline 3 & 811 & 356 & $43.9 * * *$ & $(22.1,28.0)$ & 3 & 573 & 172 & $30.0 *$ & $(21.5,28.6)$ \\
\hline 4 & 244 & 109 & $44.7 * * *$ & $(19.8,30.6)$ & 4 & 138 & 45 & $32.6 *$ & $(18.1,32.6)$ \\
\hline \multicolumn{5}{|c|}{ 1st \& 4th Combined Quartiles: } & \multicolumn{5}{|c|}{ 2nd \& 3rd Combined Quartiles: } \\
\hline 1 & 15,263 & 5,282 & $34.6 * * *$ & $(24.3,25.7)$ & 1 & 16,858 & 4,840 & $28.7 * * *$ & $(24.3,25.7)$ \\
\hline 2 & 4,346 & 1,707 & $39.3 * * *$ & $(23.7,26.3)$ & 2 & 4,247 & 1,303 & $30.7^{* * *}$ & $(23.7,26.3)$ \\
\hline 3 & 1,341 & 562 & $41.9 * * *$ & $(22.7,27.4)$ & 3 & 1,133 & 338 & $29.8 *$ & $(22.5,27.6)$ \\
\hline 4 & 407 & 176 & $43.2 * * *$ & $(20.9,29.3)$ & 4 & 280 & 82 & 29.3 & $(20.1,30.3)$ \\
\hline
\end{tabular}

This article is (c) Emerald Group Publishing and permission has been granted for this version to appear here (http://centaur.reading.ac.uk/). Emerald does not grant permission for this article to be further copied / distributed or hosted elsewhere without the express permission from Emerald Group Publishing Limited. 
Table 3 (continued)

Annual Return Persistence for Various Holding Periods

\begin{tabular}{|c|c|c|c|c|c|c|c|c|c|}
\hline \multirow[b]{2}{*}{$\begin{array}{l}\text { Length } \\
\text { of Run }\end{array}$} & \multicolumn{9}{|c|}{ Panel C: 11-- to 15-year Holding Period } \\
\hline & $\begin{array}{c}\text { No. of } \\
\text { Samples }\end{array}$ & $\begin{array}{c}\text { No. of } \\
\text { Successes }\end{array}$ & $\begin{array}{c}\% \text { of } \\
\text { Successes } \\
\end{array}$ & $\begin{array}{r}\text { 95\% Conf. } \\
\text { Interval } \\
\end{array}$ & $\begin{array}{l}\text { Length } \\
\text { of Run }\end{array}$ & $\begin{array}{c}\text { No. of } \\
\text { Samples }\end{array}$ & $\begin{array}{c}\text { No. of } \\
\text { Successes } \\
\end{array}$ & $\begin{array}{c}\% \text { of } \\
\text { Successes } \\
\end{array}$ & $\begin{array}{r}95 \% \text { Conf. } \\
\text { Interval } \\
\end{array}$ \\
\hline \multicolumn{5}{|c|}{ 1st Quartile: } & \multicolumn{5}{|c|}{ 2nd Quartile: } \\
\hline 1 & 5,032 & 1,477 & $29.4 * * *$ & $(23.8,26.2)$ & 1 & 5,656 & 1,562 & $27.6 * *$ & $(23.9,26.1)$ \\
\hline 2 & 1,333 & 461 & $34.6 * * *$ & $(22.8,27.2)$ & 2 & 1,453 & 398 & $27.4 *$ & $(22.8,27.3)$ \\
\hline 3 & 411 & 158 & $38.4 * * *$ & $(21.2,29.1)$ & 3 & 363 & 95 & 26.2 & $(20.7,29.6)$ \\
\hline 4 & 140 & 46 & $32.9 *$ & $(18.6,32.1)$ & 4 & 88 & 23 & 26.1 & $(16.5,34.6)$ \\
\hline \multicolumn{5}{|c|}{ 4th Quartile: } & \multicolumn{5}{|c|}{ 3rd Quartile: } \\
\hline 1 & 5,885 & 2,117 & $36.0 * * *$ & $(23.9,26.1)$ & 1 & 6,147 & 1738 & $28.3 * * *$ & $(23.9,26.1)$ \\
\hline 2 & 1,846 & 665 & $36.0 * * *$ & $(23.2,26.9)$ & 2 & 1,619 & 482 & $29.8 * *$ & $(22.9,27.1)$ \\
\hline 3 & 544 & 183 & $33.6 * *$ & $(21.8,28.4)$ & 3 & 443 & 142 & $32.1 *$ & $(21.1,29.1)$ \\
\hline 4 & 138 & 50 & $36.2 *$ & $(19.0,31.5)$ & 4 & 126 & 44 & $34.9 *$ & $(17.8,33.0)$ \\
\hline \multicolumn{5}{|c|}{ 1st \& 4th Combined Quartiles: } & \multicolumn{5}{|c|}{ 2nd \& 3rd Combined Quartiles: } \\
\hline 1 & 10,917 & 3,594 & $32.9 * * *$ & $(24.2,25.8)$ & 1 & 11,803 & 3,300 & $28.0 * * *$ & $(24.2,25.8)$ \\
\hline 2 & 3,179 & 1,126 & $35.4 * * *$ & $(23.6,26.4)$ & 2 & 3,072 & 880 & $28.6 * *$ & $(23.5,26.5)$ \\
\hline 3 & 544 & 341 & $35.7 * * *$ & $(22.5,27.6)$ & 3 & 806 & 237 & $29.4 *$ & $(22.1,28.1)$ \\
\hline 4 & 138 & 96 & $34.5 *$ & $(20.6,29.7)$ & 4 & 214 & 67 & $31.3 *$ & $(19.4,31.0)$ \\
\hline
\end{tabular}

Panel D: 16- to 20-year Holding Period

\begin{tabular}{|c|c|c|c|c|c|c|c|c|c|}
\hline $\begin{array}{l}\text { Length } \\
\text { of Run }\end{array}$ & $\begin{array}{c}\text { No. of } \\
\text { Samples }\end{array}$ & $\begin{array}{c}\text { No. of } \\
\text { Successes }\end{array}$ & $\begin{array}{c}\% \text { of } \\
\text { Successes }\end{array}$ & $\begin{array}{r}\text { 95\% Conf. } \\
\text { Interval } \\
\end{array}$ & $\begin{array}{l}\text { Length } \\
\text { of Run }\end{array}$ & $\begin{array}{c}\text { No. of } \\
\text { Samples }\end{array}$ & $\begin{array}{c}\text { No. of } \\
\text { Successes }\end{array}$ & $\begin{array}{c}\% \text { of } \\
\text { Successes }\end{array}$ & $\begin{array}{r}95 \% \text { Conf. } \\
\text { Interval } \\
\end{array}$ \\
\hline \multicolumn{5}{|c|}{ 1st Quartile: } & \multicolumn{5}{|c|}{ 2nd Quartile: } \\
\hline 1 & 1,401 & 455 & $32.5 * * *$ & $(22.8,27.3)$ & 1 & 1,540 & 449 & $29.2 *$ & $(22.9,27.2)$ \\
\hline 2 & 417 & 150 & $36.0 * *$ & $(21.0,29.3)$ & 2 & 420 & 126 & $30.0 *$ & $(21.0,29.3)$ \\
\hline 3 & 135 & 54 & $40.0 * *$ & $(18.1,32.7)$ & 3 & 118 & 37 & 31.4 & $(17.6,33.2)$ \\
\hline 4 & 46 & 17 & 37.0 & $(13.6,38.6)$ & 4 & 35 & 12 & 34.3 & $(12.1,40.8)$ \\
\hline \multicolumn{5}{|c|}{ 4th Quartile: } & \multicolumn{5}{|c|}{ 3rd Quartile: } \\
\hline 1 & 1,598 & 603 & $37.7 * * *$ & $(22.9,27.2)$ & 1 & 1,679 & 474 & $28.2 *$ & $(23.0,27.1)$ \\
\hline 2 & 552 & 221 & $40.0 * * *$ & $(21.5,28.7)$ & 2 & 447 & 122 & 27.3 & $(21.1,29.1)$ \\
\hline 3 & 196 & 74 & $37.8 * *$ & $(19.2,31.3)$ & 3 & 117 & 25 & 21.4 & $(17.6,33.3)$ \\
\hline 4 & 65 & 22 & 33.8 & $(15.2,36.3)$ & 4 & 24 & 4 & 16.7 & $(9.8,44.4)$ \\
\hline
\end{tabular}

1st \& 4th Combined Quartiles:

$\begin{array}{lrrlrrrrrr}1 & 2,999 & 1,058 & 35.3 * * * & (23.5,26.6) & 1 & 3,219 & 923 & 28.7 * * & (23.5,26.5) \\ 2 & 969 & 371 & 38.3^{* * *} & (22.3,27.8) & 2 & 867 & 248 & 28.6 * & (22.2,27.9) \\ 3 & 331 & 128 & 38.7 * * * & (20.5,29.8) & 3 & 235 & 62 & 26.4 & (19.7,30.7) \\ 4 & 111 & 39 & 35.1^{*} & (17.4,33.5) & 4 & 59 & 16 & 27.1 & (14.8,36.9)\end{array}$

* $\quad$ Null hypothesis rejected at the $5 \%$ level of significance

* * Null hypothesis rejected at the $0.01 \%$ level of significance

$* * * \quad$ Null hypothesis rejected at the $0.00001 \%$ level of significance

This article is (c) Emerald Group Publishing and permission has been granted for this version to appear here (http://centaur.reading.ac.uk/). Emerald does not grant permission for this article to be further copied / distributed or hosted elsewhere without the express permission from Emerald Group Publishing Limited. 
Table 4

Annual Return Persistence in Up and Down Markets

\begin{tabular}{|c|c|c|c|c|c|c|c|c|c|}
\hline \multirow[b]{2}{*}{$\begin{array}{l}\text { Length } \\
\text { of Run }\end{array}$} & \multicolumn{9}{|c|}{$\begin{array}{l}\text { Panel A: All Properties in Up Markets } \\
1986 \text { to } 1989 \text { and } 1996 \text { to } 2002\end{array}$} \\
\hline & $\begin{array}{c}\text { No. of } \\
\text { Samples }\end{array}$ & $\begin{array}{c}\text { No. of } \\
\text { Successes }\end{array}$ & $\begin{array}{c}\% \text { of } \\
\text { Successes }\end{array}$ & $\begin{array}{l}\text { 95\% Conf. } \\
\text { Interval }\end{array}$ & $\begin{array}{l}\text { Length } \\
\text { of Run }\end{array}$ & $\begin{array}{l}\text { No. of } \\
\text { Samples }\end{array}$ & $\begin{array}{c}\text { No. of } \\
\text { Successes }\end{array}$ & $\begin{array}{c}\% \text { of } \\
\text { Successes }\end{array}$ & $\begin{array}{l}\text { 95\% Conf. } \\
\text { Interval }\end{array}$ \\
\hline \multicolumn{5}{|c|}{ 1st Quartile: } & \multicolumn{5}{|c|}{ 2nd Quartile: } \\
\hline 1 & 20,701 & 7,108 & 34.3 *** & $(24.4,25.6)$ & 1 & 20,911 & 5,690 & 27.2 *** & $(23.9,26.1)$ \\
\hline 2 & 4,911 & 1,760 & $35.8 * * *$ & $(24.0,26.0)$ & 2 & 3,910 & 1,140 & $29.2 * * *$ & $(23.7,26.4)$ \\
\hline 3 & 1,181 & 462 & $39.1 * * *$ & $(23.0,27.1)$ & 3 & 721 & 190 & 27.2 & $(21.9,28.2)$ \\
\hline 4 & 296 & 121 & $40.9 * * *$ & $(21.2,29.1)$ & 4 & 105 & 24 & 22.9 & (17.2,33.8) \\
\hline \multicolumn{5}{|c|}{ 4th Quartile: } & \multicolumn{4}{|c|}{ 3rd Quartile: } & \\
\hline 1 & 19,592 & 7,168 & $36.6 * * *$ & $(24.4,25.6)$ & 1 & 20,754 & 5,656 & $27.3 * * *$ & $(24.4,25.6)$ \\
\hline 2 & 4,457 & 1,613 & $36.2 * * *$ & $(24.0,26.0)$ & 2 & 3,804 & 1,082 & $28.4 * *$ & $(23.6,26.4)$ \\
\hline 3 & 963 & 337 & $35.0 * * *$ & $(22.9,27.1)$ & 3 & 689 & 181 & 26.3 & $(21.8,28.3)$ \\
\hline 4 & 175 & 61 & $34.9 *$ & $(20.5,29.8)$ & 4 & 96 & 23 & 24.0 & $(16.9,34.2)$ \\
\hline \multicolumn{5}{|c|}{ 1st \& 4th Combined Quartiles: } & \multicolumn{5}{|c|}{ 2nd \& 3rd Combined Quartiles: } \\
\hline 1 & 40,293 & 14,276 & $35.4 * * *$ & $(24.2,25.8)$ & 1 & 41,665 & 11,346 & $27.2 * * *$ & $(24.6,25.4)$ \\
\hline 2 & 9,368 & 3,373 & $36.0 * * *$ & $(23.6,26.4)$ & 2 & 7,714 & 2,222 & $28.8 * * *$ & $(24.0,26.0)$ \\
\hline 3 & 2,144 & 799 & 37.3 *** & $(22.5,27.6)$ & 3 & 1,410 & 377 & 26.7 & $(22.8,27.3)$ \\
\hline 4 & 471 & 182 & $38.6 * * *$ & $(20.6,29.7)$ & 4 & 201 & 47 & 23.4 & (19.3,31.2) \\
\hline
\end{tabular}

Panel B: All Properties in Down Markets 1981 to 1985 and 1990 to 1995

\begin{tabular}{|c|c|c|c|c|c|c|c|c|c|}
\hline $\begin{array}{l}\text { Length } \\
\text { of Run }\end{array}$ & $\begin{array}{c}\text { No. of } \\
\text { Samples } \\
\end{array}$ & $\begin{array}{c}\text { No. of } \\
\text { Successes }\end{array}$ & $\begin{array}{c}\% \text { of } \\
\text { Successes }\end{array}$ & $\begin{array}{r}95 \% \text { Conf. } \\
\text { Interval } \\
\end{array}$ & $\begin{array}{l}\text { Length } \\
\text { of Run }\end{array}$ & $\begin{array}{c}\text { No. of } \\
\text { Samples }\end{array}$ & $\begin{array}{c}\text { No. of } \\
\text { Successes }\end{array}$ & $\begin{array}{c}\% \text { of } \\
\text { Successes }\end{array}$ & $\begin{array}{r}95 \% \text { Conf. } \\
\text { Interval } \\
\end{array}$ \\
\hline \multicolumn{5}{|c|}{ 1st Quartile: } & \multicolumn{5}{|c|}{ 2nd Quartile: } \\
\hline 1 & 26,170 & 9,010 & $34.4 * * *$ & $(24.5,25.5)$ & 1 & 26,477 & 7,929 & $29.9 * * *$ & $(24.5,25.5)$ \\
\hline 2 & 6,580 & 2,827 & $43.0 * * *$ & $(24.0,26.1)$ & 2 & 5,977 & 2,004 & $35.5 * * *$ & $(23.9,26.1)$ \\
\hline 3 & 2,003 & 952 & $47.5 * * *$ & $(23.1,26.9)$ & 3 & 1,415 & 528 & $37.3 * * *$ & $(22.8,27.3)$ \\
\hline 4 & 615 & 320 & $52.0 * * *$ & $(21.7,28.5)$ & 4 & 321 & 130 & $40.5 * * *$ & $(20.4,29.9)$ \\
\hline \multicolumn{5}{|c|}{ 4th Quartile: } & \multicolumn{5}{|c|}{ 3rd Quartile: } \\
\hline 1 & 25,669 & 9,651 & $37.6 * * *$ & $(24.5,25.5)$ & 1 & 26,484 & 26,484 & $28.6 * * *$ & $(24.5,25.5)$ \\
\hline 2 & 6,913 & 3,080 & $44.6 * * *$ & $(24.0,26.0)$ & 2 & 5,650 & 7,566 & $30.8 * * *$ & $(23.9,26.1)$ \\
\hline 3 & 2,131 & 964 & $45.2 * * *$ & $(23.2,26.9)$ & 3 & 1,257 & 1,738 & $32.2 * * *$ & $(22.6,27.4)$ \\
\hline 4 & 579 & 263 & $45.4 * * *$ & $(21.6,28.6)$ & 4 & 258 & 95 & $36.8 *$ & $(19.9,30.5)$ \\
\hline \multicolumn{5}{|c|}{ 1st \& 4th Combined Quartiles: } & \multicolumn{5}{|c|}{ 2nd \& 3rd Combined Quartiles: } \\
\hline 1 & 51,839 & 18,661 & $36.0 * * *$ & $(24.6,25.4)$ & 1 & 52,961 & 15,495 & $29.3 * * *$ & $(24.6,25.4)$ \\
\hline 2 & 13,493 & 5,907 & $43.8 * * *$ & $(24.3,25.7)$ & 2 & 11,627 & 3,742 & $32.2 * * *$ & $(24.2,25.8)$ \\
\hline 3 & 4,134 & 1,916 & $46.3 * * *$ & $(23.7,26.3)$ & 3 & 2,672 & 933 & $34.9 * * *$ & $(23.4,26.7)$ \\
\hline 4 & 579 & 583 & $48.8 * * *$ & $(22.6,27.5)$ & 4 & 579 & 225 & $38.9 * * *$ & $(21.6,28.6)$ \\
\hline
\end{tabular}

This article is (c) Emerald Group Publishing and permission has been granted for this version to appear here (http://centaur.reading.ac.uk/). Emerald does not grant permission for this article to be further copied / distributed or hosted elsewhere without the express permission from Emerald Group Publishing Limited. 
Table 4 (continued)

Annual Return Persistence in Up and Down Markets

\section{Panel C: Office Properties in Up Markets 1986 to 1989 and 1996 to 2002}

\begin{tabular}{|c|c|c|c|c|c|c|c|c|c|}
\hline $\begin{array}{l}\text { Length } \\
\text { of Run }\end{array}$ & $\begin{array}{c}\text { No. of } \\
\text { Samples }\end{array}$ & $\begin{array}{c}\text { No. of } \\
\text { Successes }\end{array}$ & $\begin{array}{c}\% \text { of } \\
\text { Successes }\end{array}$ & $\begin{array}{l}\text { 95\% Conf. } \\
\text { Interval }\end{array}$ & $\begin{array}{l}\text { Length } \\
\text { of Run }\end{array}$ & $\begin{array}{c}\text { No. of } \\
\text { Samples }\end{array}$ & $\begin{array}{c}\text { No. of } \\
\text { Successes }\end{array}$ & $\begin{array}{c}\% \text { of } \\
\text { Successes }\end{array}$ & $\begin{array}{l}\text { 95\% Conf. } \\
\text { Interval }\end{array}$ \\
\hline \multicolumn{5}{|c|}{ 1st Quartile: } & \multicolumn{5}{|c|}{ 2nd Quartile: } \\
\hline 1 & 6,510 & 2,494 & $38.3 * * *$ & $(24.0,26.1)$ & 1 & 6,026 & 1,679 & $27.9 * *$ & $(23.9,26.1)$ \\
\hline 2 & 1,761 & 662 & $37.6 * * *$ & $(23.0,27.1)$ & 2 & 1,152 & 321 & $27.9 *$ & $(22.5,27.5)$ \\
\hline 3 & 442 & 175 & $39.6 * * *$ & $(21.1,29.1)$ & 3 & 199 & 52 & 26.1 & $(19.2,31.3)$ \\
\hline 4 & 117 & 44 & 37.6 & $(17.6,33.3)$ & 4 & 26 & 6 & 23.1 & $(10.3,43.6)$ \\
\hline \multicolumn{5}{|c|}{ 4th Quartile: } & \multicolumn{5}{|c|}{ 3rd Quartile: } \\
\hline 1 & 5,095 & 1,812 & $35.6 * * *$ & $(23.8,26.2)$ & 1 & 5,559 & 1,382 & 24.9 & $(23.9,26.1)$ \\
\hline 2 & 1,065 & 316 & $29.7 *$ & $(22.4,27.6)$ & 2 & 904 & 239 & 26.4 & $(22.2,27.9)$ \\
\hline 3 & 190 & 44 & 23.2 & $(19.1,31.4)$ & 3 & 148 & 37 & 30.4 & $(18.4,32.3)$ \\
\hline 4 & 23 & 10 & 43.5 & $(9.5,44.9)$ & 4 & 18 & 4 & 22.2 & $(7.8,47.8)$ \\
\hline \multicolumn{5}{|c|}{ 1st \& 4th Combined Quartiles: } & \multicolumn{5}{|c|}{ 2nd \& 3rd Combined Quartiles: } \\
\hline 1 & 11,605 & 4,306 & $37.1 * * *$ & $(24.2,25.8)$ & 1 & 11,585 & 3,061 & $26.4 *$ & $(24.2,25.8)$ \\
\hline 2 & 2,826 & 978 & $34.6 * * *$ & $(23.4,26.6)$ & 2 & 2,056 & 560 & $27.2 *$ & $(23.2,26.9)$ \\
\hline 3 & 632 & 219 & $34.7 * * *$ & $(21.7,28.5)$ & 3 & 347 & 89 & 28.0 & $(20.6,29.7)$ \\
\hline 4 & 140 & 54 & $38.6 *$ & $(18.2,32.5)$ & 4 & 44 & 10 & 22.7 & $(13.3,38.9)$ \\
\hline
\end{tabular}

Panel D: Office Properties in Down Markets 1981 to 1985 and 1990 to 1995

\begin{tabular}{|c|c|c|c|c|c|c|c|c|c|}
\hline $\begin{array}{l}\text { Length } \\
\text { of Run }\end{array}$ & $\begin{array}{l}\text { No. of } \\
\text { Samples }\end{array}$ & $\begin{array}{c}\text { No. of } \\
\text { Successes }\end{array}$ & $\begin{array}{c}\% \text { of } \\
\text { Successes }\end{array}$ & $\begin{array}{r}95 \% \text { Conf. } \\
\text { Interval } \\
\end{array}$ & $\begin{array}{l}\text { Length } \\
\text { of Run }\end{array}$ & $\begin{array}{c}\text { No. of } \\
\text { Samples }\end{array}$ & $\begin{array}{c}\text { No. of } \\
\text { Successes }\end{array}$ & $\begin{array}{c}\% \text { of } \\
\text { Successes }\end{array}$ & $\begin{array}{l}95 \% \text { Conf. } \\
\text { Interval }\end{array}$ \\
\hline \multicolumn{5}{|c|}{ 1st Quartile: } & \multicolumn{5}{|c|}{ 2nd Quartile: } \\
\hline 1 & 6,397 & 1,813 & $28.3 * * *$ & $(23.9,26.1)$ & 1 & 7,172 & 1,964 & $27.4 * *$ & $(24.0,26.0)$ \\
\hline 2 & 1,222 & 465 & $38.1 * * *$ & $(22.6,27.5)$ & 2 & 1,477 & 488 & 33.0 *** & $(22.8,27.2)$ \\
\hline 3 & 302 & 141 & $46.7 * * *$ & $(20.3,30.0)$ & 3 & 339 & 135 & $39.8 * * *$ & $(20.5,29.8)$ \\
\hline 4 & 84 & 47 & $56.0 * * *$ & $(16.3,34.9)$ & 4 & 87 & 30 & 34.5 & $(16.9,34.7)$ \\
\hline \multicolumn{5}{|c|}{ 4th Quartile: } & \multicolumn{5}{|c|}{ 3rd Quartile: } \\
\hline 1 & 10,051 & 4,530 & $45.1^{* * *}$ & $(24.2,25.9)$ & 1 & 8,350 & 2,504 & $30.0 * * *$ & $(24.1,25.9)$ \\
\hline 2 & 3,311 & 1,604 & $48.4 * * *$ & $(23.5,26.5)$ & 2 & 1,936 & 631 & $32.6 * * *$ & $(23.1,27.0)$ \\
\hline 3 & 1,114 & 227 & $46.9 * * *$ & $(22.5,27.6)$ & 3 & 466 & 151 & $32.4 *$ & $(21.2,29.0)$ \\
\hline 4 & 312 & 152 & $48.7 * * *$ & $(20.4,30.0)$ & 4 & 97 & 29 & 29.9 & $(16.9,34.1)$ \\
\hline \multicolumn{5}{|c|}{ 1st \& 4th Combined Quartiles: } & \multicolumn{5}{|c|}{ 2nd \& 3rd Combined Quartiles: } \\
\hline 1 & 16,448 & 6,343 & $38.6 * * *$ & $(24.3,25.7)$ & 1 & 15,522 & 4,468 & $28.8 * * *$ & $(24.3,25.7)$ \\
\hline 2 & 4,533 & 2,069 & $45.6 * * *$ & $(23.8,26.3)$ & 2 & 3,413 & 1,119 & $32.8 * * *$ & $(23.6,26.5)$ \\
\hline 3 & 1,416 & 368 & $46.8 * * *$ & $(22.8,27.3)$ & 3 & 805 & 286 & $35.5^{* * *}$ & $(22.1,28.1)$ \\
\hline 4 & 396 & 199 & $50.3 * * *$ & $(20.9,29.4)$ & 4 & 184 & 59 & $32.1 *$ & $(19.0,31.5)$ \\
\hline
\end{tabular}

* $\quad$ Null hypothesis rejected at the $5 \%$ level of significance

** $\quad$ Null hypothesis rejected at the $0.01 \%$ level of significance

*** $\quad$ Null hypothesis rejected at the $0.00001 \%$ level of significance

This article is (c) Emerald Group Publishing and permission has been granted for this version to appear here (http://centaur.reading.ac.uk/). Emerald does not grant permission for this article to be further copied / distributed or hosted elsewhere without the express permission from Emerald Group Publishing Limited. 
Table 5

Panel A: Lease Terms Equally Weighted within IPD Database by Starting Year*

\begin{tabular}{lrrrr} 
Property Type & Year & $\begin{array}{r}\text { Average Term } \\
\text { in Years }\end{array}$ & $\begin{array}{r}\text { Median Term } \\
\text { in Years }\end{array}$ & $\begin{array}{r}\text { Number of } \\
\text { Leases }\end{array}$ \\
\hline Office & $2003 / 4$ & 6.7 & & 1,717 \\
& 2002 & 7.6 & & 1,553 \\
& 2001 & 7.9 & & 1,612 \\
& 2000 & 8.5 & 1,782 \\
\cline { 2 - 5 } Retail & $2000-04$ & 7.7 & 6,664 \\
& $2003 / 4$ & & \\
& 2002 & 9.6 & 4,042 \\
& 2001 & 9.8 & 3,038 \\
& 2000 & 9.7 & 3,218 \\
Industrial & $2000-04$ & 9.6 & 2,925 \\
& $2003 / 4$ & 9.7 & \\
& 2002 & 5.7 & 2,223 \\
& 2001 & 7.3 & 1,215 \\
& 2000 & 8.5 & 2,230 \\
& $2000-04$ & 7.5 & 1,540 \\
& & 7.3 &
\end{tabular}

Panel B: Lease Terms Equally Weighted within RREEF-Managed Portfolios by Starting Year

\begin{tabular}{lrrrr} 
Property Type & Year & $\begin{array}{r}\text { Average Term } \\
\text { in Years }\end{array}$ & $\begin{array}{r}\text { Median Term } \\
\text { in Years }\end{array}$ & $\begin{array}{r}\text { Number of } \\
\text { Leases }\end{array}$ \\
\hline Office & 2004 & 4.5 & 4.0 & 184 \\
& 2003 & 4.1 & 3.3 & 679 \\
& 2002 & 5.0 & 5.0 & 190 \\
& 2001 & 5.2 & 5.0 & 150 \\
& 2000 & 6.6 & 5.1 & 164 \\
\cline { 2 - 5 } & $2000-04$ & 4.6 & 4.59 & 1,367 \\
Retail & & & & \\
& 2004 & 4.6 & 5.0 & 84 \\
& 2003 & 5.8 & 5.0 & 224 \\
& 2002 & 5.8 & 5.0 & 83 \\
& 2001 & 6.0 & 5.1 & 41 \\
& 2000 & 6.4 & 5.0 & 56 \\
\cline { 2 - 5 } Industrial & $2000-04$ & 5.7 & 5.0 & 488 \\
& & & & \\
& 2004 & 3.0 & 3.0 & 723 \\
& 2003 & 3.0 & 3.0 & 2,201 \\
& 2002 & 3.6 & 3.0 & 723 \\
& 2001 & 4.5 & 4.4 & 449 \\
& 2000 & 5.4 & 5.0 & 395 \\
\cline { 2 - 5 } & $2000-04$ & 3.4 & 3.0 & 4,491
\end{tabular}

* Figures from BPF/IPD (2004). 2003/4 figures are for all of 2003 plus the first three calendar months of 2004. The median term column is intentionally left blank but included to be consistent with Panel B. 